\title{
Development of Certain Protein Kinase Inhibitors with the Components from Traditional Chinese Medicine
}

OPEN ACCESS

Edited by:

Amit K. Tiwari,

University of Toledo, USA

Reviewed by:

Wang Lingzhi,

National University of Singapore

Singapore

Hemlata Sukhija,

Children's Hospital Los Angeles, USA

Amarjit Luniwal,

North American Science Associates,

Inc., USA

${ }^{*}$ Correspondence:

Xiukun Lin

linxiukun@yahoo.com

${ }^{\dagger}$ These authors have contributed equally to this work.

${ }^{\ddagger}$ Co-first authors.

Specialty section:

This article was submitted to Pharmacology of Anti-Cancer Drugs,

a section of the journal

Frontiers in Pharmacology

Received: 13 September 2016 Accepted: 15 December 2016 Published: 09 January 2017

Citation:

Liu M, Zhao G, Cao S, Zhang Y, Li X and Lin X (2017) Development of Certain Protein Kinase Inhibitors with the Components from Traditional

Chinese Medicine.

Front. Pharmacol. 7:523.

doi: 10.3389/fphar.2016.00523

\author{
Minghua Liu ${ }^{\dagger \neq}$, Ge Zhao ${ }^{\ddagger \neq}$, Shousong Cao, Yangyang Zhang, Xiaofang Li and Xiukun Lin * \\ Department of Pharmacology, School of Pharmacy, Southwest Medical University, Luzhou, China
}

Traditional Chinese medicines (TCMs) have been used in China for more than two thousand years, and some of them have been confirmed to be effective in cancer treatment. Protein kinases play critical roles in control of cell growth, proliferation, migration, survival, and angiogenesis and mediate their biological effects through their catalytic activity. In recent years, numerous protein kinase inhibitors have been developed and are being used clinically. Anticancer TCMs represent a large class of bioactive substances, and some of them display anticancer activity via inhibiting protein kinases to affect the phosphoinositide 3-kinase, serine/threonine-specific protein kinases, pechanistic target of rapamycin (PI3K/AKT/mTOR), P38, mitogen-activated protein kinase (MAPK) and extracellular signal-regulated kinases (ERK) pathways. In the present article, we comprehensively reviewed several components isolated from anticancer TCMs that exhibited significantly inhibitory activity toward a range of protein kinases. These components, which belong to diverse structural classes, are reviewed herein, based upon the kinases that they inhibit. The prospects and problems in development of the anticancer TCMs are also discussed.

Keywords: Traditional Chinese Medicine, protein kinase inhibitors, anticancer activity, PI3K/AKT/mTOR, MAPK, ERK

\section{INTRODUCTION}

The protein kinase family encompasses all enzymes in the human body that catalyze the transfer of a phosphate group from a high energy molecule such as adenine triphosphate (ATP) to a specific amino acid in a protein. The human genome codes for more than 500 different protein kinases, which are divided into different families according to their selectivity for substrates (Sharma et al., 2008). Protein kinases play important roles in regulating cellular functions, including proliferation, survival, apoptosis, motility as well as metabolism and DNA damage repair, etc. Protein kinases such as cellular Src (c-Src), c-Abl, mitogen activated protein kinase (MAPK), phosphotidylinositol3- kinase (PI3K), serine/threonine -specific protein kinase (AKT) and the epidermal growth factor receptor (EGFR), are commonly activated in cancer cells and known to play roles in tumorigenesis. Many of these occur in the same signaling pathway; EGFR kinase family members (HER1 [EGFR], HER2, HER3, and HER4) transmit signals through MAPK and PI3K to promote cell proliferation (Goldstein et al., 2008). The central role of kinases in virtually all networks of signal transduction is the driving motivation useful for the development of compounds modulating their activities (Ferré et al., 2014). 
In the past decades, numerous natural compounds with inhibitory effects on protein kinases have been identified or developed and some of them have been approved by the Federal Administration Agency (FDA) in the United States and used successfully in the treatment of human cancers clinically. In recent years, an increasing number of novel compounds have been isolated from Traditional Chinese Medicines (TCMs), and many of them have been reported to possess potent anticancer activity via inhibition of protein kinase mediated signaling pathways, including PI3K/AKT/mTOR, P38 MAPK, and ERK (Figure 1). In this mini-review, we focus on those compounds isolated from TCMs with inhibitory effects on protein kinases and present an overview of their anticancer effects and potentials in pharmaceutics for cancer therapy.

\section{COMPONENTS ISOLATED FROM TCMS THAT INHIBIT MAPK}

MAPK, a serine/threonine specific protein kinase, regulates a variety of biological processes including cell survival, proliferation, differentiation, and apoptosis through downstream signal transduction cascades (Sun et al., 2010). The classical MAPK family consists of three subfamilies, i.e., the ERKs, the c-Jun $\mathrm{N}$-terminal kinases (JNKs)/stress-activated protein kinases (SAPKs), and the p38 MAPKs (Chang and Karin, 2001; Kannan-Thulasiraman et al., 2006). JNKs and p38 MAPKs play critical roles in the signaling mechanisms that orchestrate cellular response to various types of cellular stress (Dhanasekaran and Reddy, 2008; Wagner and Nebreda, 2009). It has been acknowledged that the ERK signaling pathway is also very important in carcinogenesis. Selective inhibitors of these kinases are likely to affect cellular events with high specificities and are therefore the molecules of significant interest for discovery and development of anticancer pharmaceuticals (Nakao and Fusetani, 2007).

Curcuma longa $L$. is an important herb used in TCM to treat various types of pain and inflammation. Curcumin (Figure 2), an apolyphenolic compound, is isolated from the rhizomes of Curcuma longa L.. Recent studies have shown that curcumin has anti-tumor effect to inhibit cell proliferation and promote cell apoptosis in several types of cancer including hepatocellular carcinoma, lung cancer, breast cancer, colorectal cancer, etc. (Johnson et al., 2009; Banerjee et al., 2010; Cheng et al., 2010; Saha et al., 2010). Curcumin significantly activates the JNK and p38 MAPK, but not the ERK, signaling pathways via phosphorylation, thus down-regulating anti-apoptotic proteins Bcl-2, Bcl-XL, Mcl-1, and survivin in human HCT-116 colon cancer cells during apoptosis process (Collett and Campbell, 2004). Curcumin induces apoptosis of THP-1 human monocytic

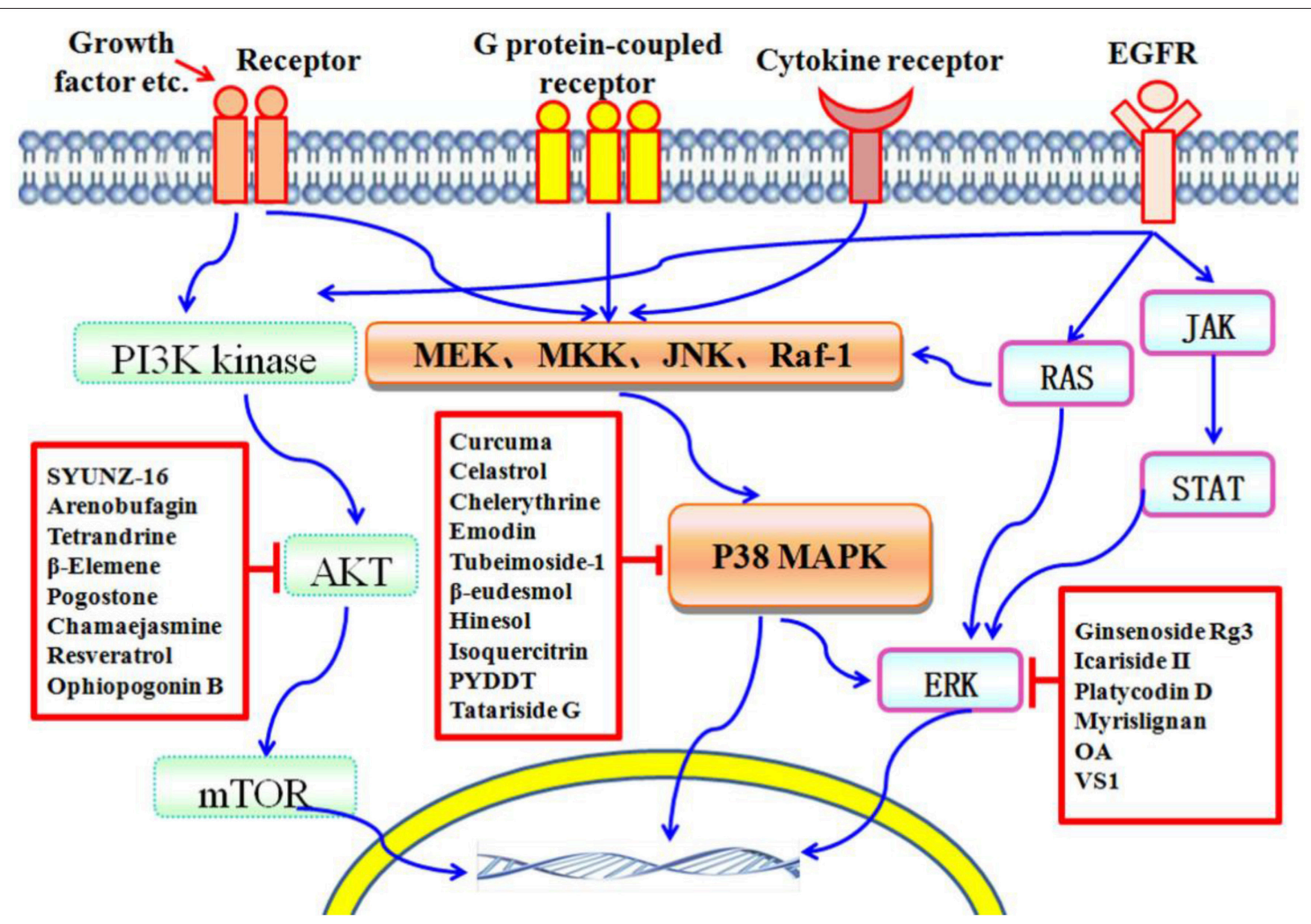

FIGURE 1 | Schematic depiction of TCM components that serve as protein kinase inhibitors. The PI3K/AKT/mTOR, P38 MAPK, and ERK pathways are important players in cell death induced by protein kinases. Many compounds isolated from TCMs are capable of inducing cell death via affecting different protein kinase pathways. 
<smiles>COc1cc(/C=C/C(=O)CC(=O)/C=C/c2ccc(O)c(OC)c2)ccc1O</smiles>

Curcumin<smiles>COc1ccc2c(c1)c(OC)c(OC)c[n+]2C</smiles>

Chelerythrine<smiles>CC1=C(O)C(=O)C=C2C1=CC=C1C3CCC4(C)CCC(C)(C[C@]4(C)C(=O)O)[C@H]3CCC21C</smiles>

Celastrol<smiles>O=C1c2cc(O)cc(O)c2C(=O)c2cc(O)cc(O)c21</smiles>

Emodin

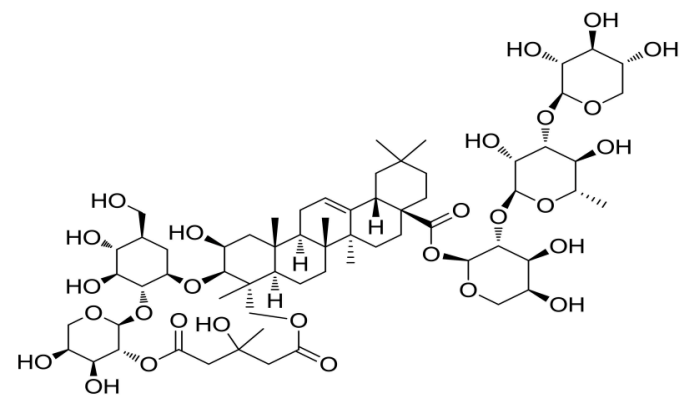

Tubeimoside-1<smiles>CC1=CCCC(C)[C@@]12CC[C@@H](C(C)(C)O)C2</smiles>

Hinesol<smiles>C=C1CCC[C@]2(C)CCC(C(C)(C)O)C[C@@H]12</smiles>

$\beta$-eudesmol<smiles>O=c1c(O[C@@H]2O[C@H](CO)[C@@H](O)[C@H](O)C2O)c(-c2ccc(O)c(O)c2)oc2cc(O)cc(O)c12</smiles>

Isoquercitrin

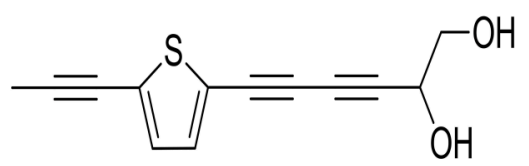

PYDDT

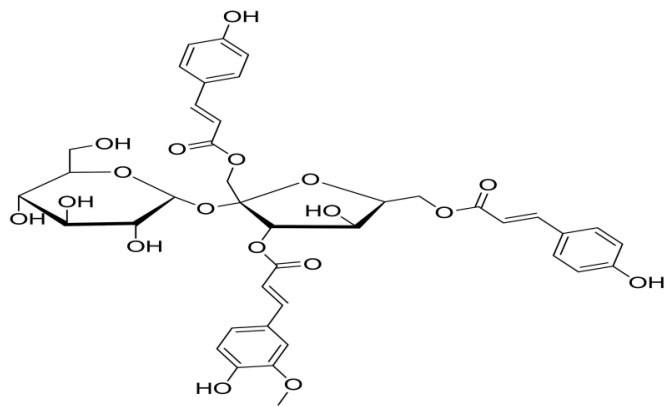

Tatariside G

FIGURE 2 | Chemical structures of components isolated from TCMs with inhibitory effects via MAPK pathway. 
leukemia cells by activation of the JNK/ERK signaling pathway (Yang et al., 2012). Curcumin can also block cell cycle progression at the $\mathrm{G}_{2} / \mathrm{M}$ phase and induce apoptosis by regulation of ERK1/2 phosphorylation in nasopharyngeal carcinoma cells (Wang et al., 2013). Curcumin halts the growth of human HepG2 liver xenograft tumors in nude mice. Curcumin downregulates the expression of $\mathrm{p}$-ERK1/2 and $\mathrm{p}$-AKT in tumor tissues by immunohistochemical analyses (Chintana et al., 2011). Furthermore, curcumin inhibits proliferation of colorectal carcinoma cells by modulating the Akt/mTOR signaling pathway (Johnson et al., 2009). Curcumin as an antitumoral agent is currently under phase II clinical development for prevention of colorectal cancer. Pharmacokinetic studies show that the absorbed curcumin conjugates with glucuronic acid and sulfate, and metabolized to glucuronic acid and sulfate conjugates in the intestine and liver (Ireson et al., 2002). Excretion of curcumin glucuronides from intestinal cells occurs predominantly at the apex and to a lesser extent at the basolateral side, thus limiting its absorption (Usta et al., 2007). In cancer patients, the serum concentration peaks at $1-2 \mathrm{~h}$ after intake and does not exceed $0.60 \mu \mathrm{g} / \mathrm{mL}(0.16 \mu \mathrm{mol} / \mathrm{L})$ even at a dose of $8 \mathrm{~g}$ curcumin per day for 3 months (Cheng et al., 2001). In a dose-escalation study, curcumin was not detected in the serum for up to $4 \mathrm{~h}$ after administration of single doses of $0.5-8.0 \mathrm{~g}$ curcuminoids, and only low concentrations between 0.03 and $0.06 \mu \mathrm{g} / \mathrm{mL}$ were detected after single oral dose of 10 or $12 \mathrm{~g}$ (Lao et al., 2006). The low bioavailability of curcumin is attributed to its limited absorption, efficient re-secretion from intestinal cells and rapid intestinal and hepatic conversion to its metabolites dihydro, tetrahydro-, and hexahydrocurcumin and their respective conjugates with glucuronic acid and sulfate, which considerable hampers its therapeutic efficacy and clinical application (Schiborr et al., 2010). Recently, the nanoparticle of curcumin was developed, and the bioavailability of the compound was greatly improved (Zhang et al., 2014).

Tripterygium wilfordii Hook. f., distributed in Asia, is another herb used in TCM to treat autoimmune and inflammatory diseases such as rheumatoid arthritis and tuberculosis. Celastrol (Figure 2), a triterpenoid isolated from the plant has attracted great attention due to its potent anticancer effects and its diverse molecular targets involved in tumorigenesis (Yang H. et al., 2006; Sethi et al., 2007; Huang et al., 2008; Peng et al., 2010; Kannaiyan et al., 2011; Lee et al., 2012; Rajendran et al., 2012). The anticancer mechanisms of the compound include inducing apoptosis in tumor cells, affecting angiogenesis, regulating the related proteins of tumor and so on. Recent studies have shown that Reactive oxygen species (ROS)/c-Jun NH2-terminal kinase (JNK) signal pathway plays a critical role in celastrol induced cell apoptosis; treatment of cancer cells with celastrol activates caspase-3, -8, 9, DR5, and cleavage of PARP, Bid, upregulates the expression of LC3B-II. The augmentation of JNK phosphorylation and ROS generation is another important event in celastrol induced cell apoptosis (Li H. Y. et al., 2015). In addition, celastrol is able to suppress the expression of vascular endothelial growth factor receptor (VEGFR), and inhibits the growth of human glioma xenografts in nude mice (Huang et al., 2008). Additionally, treatment with celastrol resulted in significant inhibition of the tumor growth without host toxicity in nude mice bearing prostate tumors (Yang H. et al., 2006). These studies suggest that celastrol is a promising candidate for development as an anticancer agent. A sensitive and precise LC-MS/MS assay was developed to determine the pharmacokinetic profiles of celastrol in rats (Zhang et al., 2012). The results showed that oral administration of pure celastrol leads only to an bioavailability of $17.06 \%$, whereas after oral administration of TGV tablets, the absolute bioavailability of celastrol in female rats increased up to $94.19 \%$, demonstrating improved absorption properties of celastrol (Zhang et al., 2012).

Chelidonium majus $L$. is used in TCM to treat ulcer and gastrointestinal pain. Chelerythrine (Figure 2) is a benzene alkaloid isolated from the herb. Chelerythrine has been proved to possess potent antitumor effect on various cancers, in particular breast, colon and prostate cancers (Chmura et al., 2000). The mechanism of action of chelerythrine involves several pathways, including cell cycle arrest andinhibition of protein synthesis. Chelerythrine activated JNK/p38 MAPK pathways in a concentration and time-dependent manners in Hela cervical cancer cells (Yu et al., 2000). Treatment of chelerythrine resulted in activation of MEK/ERK1/2 signaling pathway, up-regulation of downstream kinases (p90RSK), and finally induction of apoptosis in human osteosarcoma cells (Yang et al., 2008). Chelerythrine can also induce G1 phase arrest and bimodal cell death in human leukemia HL-60 cells (Vrba et al., 2008). In addition, chelerythrine is a specific inhibitor of protein kinase $\mathrm{C}$ (PKC), blocking PKC translocation from cytosol to membrane, contributed to the progression of apoptotic tumor cell death (Siomboing et al., 2001). Recent study also demonstrated that chelerythrine possesses the activity of inhibiting the telomerase activity and promoting cancer cell death via binding with human telomeric DNA to form the four-stranded G-quadruplex (Yang et al., 2011).

Emodin (Figure 2) is an active ingredient derived from the rhizome of Rheum palmatum L., which is widely used in TCM as a laxative over thousands years ( $\mathrm{Ma}$ and $\mathrm{Li}, 2014$; $\mathrm{Qu}$ et al., 2015). In the last decades, increased attention is focused on the anticancer activities of emodin since studies have shown that the compound exhibited the effects of antiproliferation and apoptosis-induction in a number of human cancers such as colon, cervical and gastric cancer (Yaoxian et al., 2013; Xie et al., 2014). Emodin inhibited proliferation and induced apoptosis of hepatocellular carcinoma cells both in vitro and in vivo through MAPK and PI3K/AKT signaling pathways in a dose-dependent manner (Lin et al., 2016). Emodin signifcantly activates the phosphorylation of ERK and p38, which associated with apoptosis of hepatocellular carcinoma (HCC) cells. Moreover, emodin can induce apoptosis of colorectal cancer cells through activating $\mathrm{p} 53 / \mathrm{p} 38 /$ Puma pathway by triggering ROS production (Liu et al., 2015). Pharmacokinetic study revealed that emodin was predominantly found in liver and brain after oral intake of Polygonum cuspidatum, which is a widely used in TCM (Lin et al., 2012). After intragastric administration at doses of 20 and 40 $\mathrm{mg} / \mathrm{kg}$, emodin rapidly underwent phase II metabolism to form its glucuronide derivative, and the parent form of emodin was almost undetectable in vivo (Shia et al., 2010). Glucuronidation metabolism appeared to be one of the main reasons for the very 
poor oral bioavailability of emodin as found in a cultured Caco-2 cell model (Liu et al., 2012).

Bolbostemma paniculatum (Maxim.) Franquet is used in TCM to treat swollen skin, tuberculosis and abscess of the lung. Tubeimoside-1 (Figure 2) as a novel compound with potent anticancer activity is isolated from the plant (Yin et al., 2011; Yu et al., 2001). Tubeimoside-1 inhibited the growth of several cancer cells including gliomas, lung cancer and liver cancer (Zhang et al., 2011; Wang et al., 2011a; Jia et al., 2015). Tubeimoside-1 induced phosphorylation of apoptosis signal-regulating kinase 1 (ASK-1) and its downstream target proteins JNK and p38 in a dose-dependent manner, leading to mitochondrial apoptosis in DU145 human prostate cancer cells (Yang et al., 2016). Activation of MAPK-JNK signaling pathway plays an important role in tubeimoside-1 induced cell cycle arrest in lung cancer cells (Hao et al., 2015). Tubeimoside1 can also sensitize cell response to cisplatin in cisplatinresistant human ovarian cancer cells (A2780/DDP) through down-regulation of ERK and up-regulation of p38 (Liu H. Z. et al., 2011). Tubeimoside- 1 increased the expression of $\mathrm{CHOP}$ and phosphorylated p38, resulting in $\mathrm{G}_{2} / \mathrm{M}$ phase arrest and apoptosis in SKOV-3 human ovarian carcinoma cells (Chen W. J. et al., 2012). In addition, tubeimoside-1 can induce oxidative stress-mediated apoptosis and $\mathrm{G}_{2} / \mathrm{M}$ phase arrest in HepG2 liver cancer cells via NF-KB, JNK, and p53 pathways (Yin et al., 2011). LC/MS analysis was performed to check the pharmacokinetics of tubeimoside- 1 after intravenous and oral administration in rats (Liang et al., 2007). Tubeimoside-1 was found with very slow clearance via hepatic tissues. The absolute oral bioavailability of tubeimoside- 1 was only $0.23 \%$, suggesting that tubeimoside- 1 has poor absorption or undergoes acid-induced degradation.

Atractylodes lancea rhizome is recognized to possess the diuretic and stomachic effects in TCM, and used to treat abdominal distention and dismembered sores in China. Two oil products, $\beta$-eudesmol (Figure 2) and hinesol (Figure 2) are isolated from the plant. Recent study showed that $\beta$-eudesmol is able to activate JNK/MAPK signaling pathway, and induce cell death through mitochondria-mediated intrinsic apoptosis modulated by JNK-dependent downregulation of Bcl-2 in HL60 leukemiacells ( $\mathrm{Li}$ Y. et al., 2013). $\beta$-eudesmol induced the decrease of matrix metalloproteinases (MMP) and the release of cytochrome C from mitochondria in HL60 leukemia cells accompanied with the activation of caspase-9, caspase-3, and cleavage of PARP. $\beta$-eudesmol exhibited the inhibitory effect on the growth of various cancer cells including HeLa cervical cancer, SGC-7901 gastric cancer, and liver cancer BEL-7402 cells in vitro (Tsuneki et al., 2005). Hinesol, a sesquiterpenoid component isolated from the herb, also induced apoptosis via JNK signaling pathway. Hinesol treatment significantly activated JNK and ERK, but did not alter the activation of $\mathrm{p} 38$; thus hinesol may represent a novel anticancer agent in the treatment of leukemia (Masuda et al., 2015).

Bidens bipinnata $L$. has been used in TCM as a basic drug historically in the local area of Guangxi, China, to treat many kinds of diseases such as malaria, diarrhea, dysentery, hepatitis, acute nephritis, hypertension, hyperlipidaemia, and diabetes. Isoquercitrin (Figure 2) is a favonoid compound with anticancer activity isolated from Bidens bipinnata $L$ (Yang et al., 2013; Wu et al., 2013a). Isoquercitrin strongly inhibited the phosphorylation of ERK and p38MAPK proteins while promoting the phosphorylation of JNK, thus inducing apoptosis in HepG2 liver cancer cells in a caspase -dependent manner (Huang et al., 2014). Isoquercitrin can also block the liver cancer cells at the $G_{1}$ phase and exhibited inhibitory effect on transplanted tumor growth in vivo (Huang et al., 2014).

The roots of Echinops grijsii, is believed to possess the effects of antiinflammation, detoxicating, and expelling miasma in TCM, and used to relieve the distention of the breast and stimulating milk secretion (Jin et al., 2008; Zhang et al., 2008). A thiophene derivative, 2-(Pro-1-ynyl)-5- (5,6-dihydroxypenta1,3-diynyl) thiophene (PYDDT) (Figure 2) is isolated from the herb. PYDDT induces the production of ROS, and the activation of JNK but not p38 and ERK1/2, leading to induction of mitochondrial-mediated apoptosis in human colon cancer SW620 cells (Xu et al., 2015). PYDDT-induced apoptosis was characterized by the cleavage of PARP, activation of caspase 9 and caspase 3 , release of cytochrome $\mathrm{C}$ from mitochondria, loss of mitochondrial membrane potential, down-regulation of $\mathrm{Bcl}-2$, and mitochondrial translocation of Bax.

Fagopyrum tataricum (L.) Gaertn (tartary buckwheat) has been widely used as an important folk medicine in China as a nutritional food. Studies have shown that the herb has multiple benefits including antioxidant, antitumor, antihypotensive, hypoglycemic, and hypolipidaemic effects (Lin et al., 2011; Karki et al., 2013). Tatariside G (Figure 2), a novel phenylpropanoid glycosides compound, was isolated from the roots of Fagopyrum tataricum (L.) Gaertn. Recent study revealed that tatariside G notably inhibited cell viability and induced apoptosis in human cervical cancer HeLa cells through both activation of p38/JNK phosphorylation and inhibition of Akt phosphorylation (Li et al., 2014). Tatariside $\mathrm{G}$ could elevate the cleaved protein expression of caspase- 3 and caspase- 9 in a dose-dependent manner, and decreased mitochondrial membranep potential (MMP) in HeLa cells (Li et al., 2014).

\section{COMPONENTS ISOLATED FROM TCMS TARGETING THE PHOSPHOINOSITIDE KINASE (PI3K)/SERINE/THREONINE- SPECIFIC PROTEIN KINASE (AKT)}

The PI3K signaling pathway contributes to tumor development and progression in many types of human malignancies. It is well acknowledged that activation of AKT, the major downstream effecter of PI3K, is frequently observed in human tumors (Brugge et al., 2007; Yu et al., 2012), and the activation of AKT promotes the development of cancer as well as resistance to chemotherapy and radiation therapy. Additionally, immunohistochemical analysis has shown that AKT activation is a poor prognostic factor in various cancers (LoPiccolo et al., 2007). Therefore, PI3K/AKT signaling pathway is an attractive target for cancer therapy (Hennessy et al., 2005; Crowell et al., 
2007). Several components isolated from TCMs were found to induce cell death via inhibiting PI3K/AKT pathway.

Alkannin (Figure 3) is the major active ingredient isolated from Arnebia euchroma roots, which has long been used as antiinflammation and anti-tumor herb in Chinese folk medicine (Feng et al., 2003). Studies have shown that alkannin exerted antitumor effects by inhibiting cancer cell proliferation and inducing apoptosis via inhibiting DNA topo-isomerase I/II activity, anti-telomerase activity and anti-angiogenesis (Lu et al., 2002; Yang F. et al., 2006; Lim et al., 2007). SYUNZ-16, a synthesized alkannin derivative, is one of the compounds with potent antitumor activities (Wang et al., 2006; Xie et al., 2006a,b, 2007). SYUNZ-16 displayed potent cytotoxicity in diversified cancer cell lines including nasopharyngeal carcinoma, hepatocellular cancer, leukemia, cervical cancer, gastric cancer and breast cancer. SYUNZ-16 inhibits AKT signaling pathway, and down-regulates the phosphorylation of AKT in a dose and time-dependent manner, subsequently initiating apoptotic events in Hep3B liver cancer and GLC-82 lung cancer cells (Deng et al., 2010). SYUNZ-16 can obviously inhibit the proliferation of these cancer cells via induction of apoptosis with the activation of caspase -3 and PARP cleavage (Deng et al., 2010). SYUNZ-16 can also partially attenuate the phosphorylation levels of forkhead transcription factors (FKHR and FKHRL1), which are important substrates of AKT (Tokunaga et al., 2008). SYUNZ-16 exhibits inhibitory effects on murine S-180 sarcoma allografts and GLC82 lung cancer xenografts in vivo (Deng et al., 2010).

Toad venom (venenum bufonis, also called Chan'su) is derived from the dried skin secretions of giant toads (Bufo gargarizans Cantor or Bufo melanostictus Suhneider) and has been widely used alone or in combination with other herbal ingredients for cancer treatment over centuries in China. An injectable formulation of toad venom called cinobufacin (Huchansu) was developed to treat various solid tumors in China in 1990's. Clinical studies have shown that cinobufacin significantly increased the antitumor efficacy of docetaxol or cisplatin in the combination therapy. Decreased toxicity and improved life quality were also observed in the clinical trial with cancer patients (Gong et al., 2010). Arenobufagin (Figure 3), one of the components of toad venom, was reported to have a broad spectrum of antitumor activity in cancer cells, including MCF-7, MCF-7/ADR, HepG2, and some other carcinoma cell lines (Zhang et al., 1992; Masuda et al., 1995; Yu et al., 2010). PI3K/AKT signaling pathway plays a central role in arenobufagin-mediated cell death. Arenobufagin can inhibit AKT with involvement of Phosphatase and tensin homolog (PTEN) activation as well as PDK1 and PI3K inhibition, and induces apoptosis in HCC cells. Arenobufagin treatment leads to marked decrease in the expression of mTOR. Inhibition of $\mathrm{PI} 3 \mathrm{~K} / \mathrm{AKT} / \mathrm{mTOR}$ pathway can promote the development of both autophagy and apoptosis induced by arenobufagin (Brown et al., 2003; Teachey et al., 2006; Chen G. et al., 2012). Arenobufagin induces mitochondria-mediated apoptosis in HepG2 and HepG2/ADM cells, accompanied with a decrease of mitochondrial potential, and an increase of $\mathrm{Bax} / \mathrm{Bcl}-2$ expression ratio. Activation of caspase- 3 and caspase- 9 as well as cleavage of PARP was also found in arenobufagin induced cell apoptosis (Zhang D. M. et al., 2013). In addition, arenobufagin is able to block VEGF-mediated angiogenesis (Li M. et al., 2013). Therefore, arenobufagin as the main active ingredients of toad venom has the potential to be developed as a novel anticancer agent (Liu et al., 2009; Hu et al., 2011). The pharmacokinetic characteristics of arenobufagin has been studied in six SpragueDawley rats by ultra-fast liquid chromatography-tandem mass spectrometry (Li G. et al., 2013). Arenobufagin can be detected in plasma within $5 \mathrm{~min}$ to a peak concentration of $1.98 \mathrm{ng} / \mathrm{mL}$ after intraperitoneal administration $4.0 \mathrm{mg} / \mathrm{kg}$, which indicates that arenobufagin can be absorbed quickly (Li G. et al., 2013).

Radix Stephaniae tetrandrae is used to treat the syndrome of dampness-heat related diseases in TCM over thousands of years and it is widely used to treat cystitis, prostatitis, urethritis, pyelonephritis, vaginitis as well as rheumatism in China. A bisbenzylisoquinoline alkaloid, tetrandrine (Figure 3) is isolated from the roots of Radix Stephaniae tetrandrae (Bosch et al., 2004; Liu et al., 2006). Studies have shown that tetrandrine is able to inhibit cell proliferation and induces apoptosis of cancer cells (Yan et al., 2006; Chen et al., 2008). ERK and PI3K-AKT signaling pathways play a critical role in tetrandrine induced cell apoptosis (Lin et al., 2008). Treatment of cancer cells with tetrandrine leads to the suppression of AKT activation, which in turn regulated the function of $\mathrm{Bcl}-2$ family proteins and activated caspase cascades (Liu C. Y. et al., 2011). Tetrandrine also has the potential of immunomodulation and anti-inflammatory activity, which plays a positive role in HCC therapy (Shen et al., 2001). Based on a long history of clinical application in TCM, tetrandrine is considered to be a safe agent, and may be an attractive candidate compound for liver cancer therapy. The Pharmacokinetic properties of tetrandrine were studied with a simple HPLC method in rabbits. The concentration-time data of tetrandrine fitted the classical two-compartment model, whether the drug was administered intravenously or orally (Jiang et al., 2011). The ratio of tetrandrine AUC (10 mg/ $\mathrm{kg}$ by gavage) to AUC ( $5 \mathrm{mg} / \mathrm{kg}$ by intravenous injection) was about $30 \%$ and ratio of their Cmax was less than $20 \%$, suggesting that tetrandrine is less absorbed from digestive tract or has a strong first pass effect as the gavage dose is double that of intravenous dose (Jiang et al., 2011).

Rhizoma zedoariae possesses the effects of subsiding swelling, relieving pain in TCM and used to tread rheumatalgia, headache and chestpain. Elemene (1-methyl-1- vin- yl-2,4diiso- propenyl-cyclohex-ane, Figure 3), a noval lipid-soluble component, is extracted from the rhizoma of zedoariae ( $\mathrm{Li}$ et al., 2009). $\beta$-Elemene, the most active component of elemene, has been shown to be effective against various cancers in vitro and in vivo, such as lung cancer, colorectal cancer and glioblastoma (Wang et al., 2005; Yao et al., 2008; Li et al., 2009; Xie et al., 2009). Recently, $\beta$-Elemene has been approved by the State Food and Drug Administration of China for the treatment of some solid tumors (Tan et al., 2000). $\beta$ Elemene induces apoptosis and autophagy through inhibition of the PI3K/Akt/ mTOR/p70S6K1 signaling pathway in human gastric cancer cells (Liu J. et al., 2011). Following treatment with $\beta$-Elemene, the level of phospho-AKT was obviously downregulated, leading to the down-regulation of downstream 
<smiles>[R4]C(CC=C(C)C)c1cc(O)c2c(c1O)C([R7])C(=O)C2=O</smiles>

$\mathrm{R}_{1}=\mathrm{R}_{2}=\mathrm{N}\left(\mathrm{CH}_{2} \mathrm{CH}_{2}\right)_{2} \mathrm{O}$

SYUNZ-16<smiles>COc1cccc(Oc2ccc(C[C@H]3c4cc(OC)c(OC)cc4CCN3C)cc2)c1</smiles>

\section{Tetrandrine}

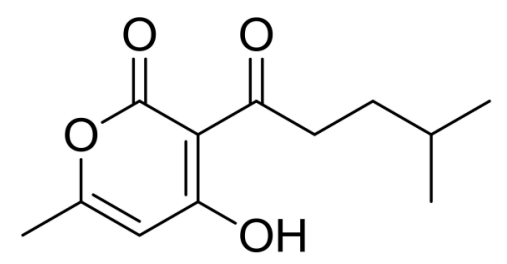

Pogostemon<smiles>Oc1ccc(/C=C/c2cc(O)cc(O)c2)cc1</smiles>

Resveratrol<smiles>C[C@]12CC[C@@H](O)C[C@H]1CC[C@H]1[C@@H]2[C@H](O)C(=O)[C@]2(O)CC[C@H](c3ccc(=O)oc3)[C@@]12C</smiles>

Arenobufagin<smiles>C=C[C@]1(C)CC[C@@H](C(=C)C)C[C@H]1C(=C)C</smiles>

阝-Elemen<smiles>O=C1c2c(O)cc(O)cc2OC(c2ccc(O)cc2)C1C1C(=O)c2c(O)cc(O)cc2OC1c1ccc(O)cc1</smiles>

Chamaejasmine

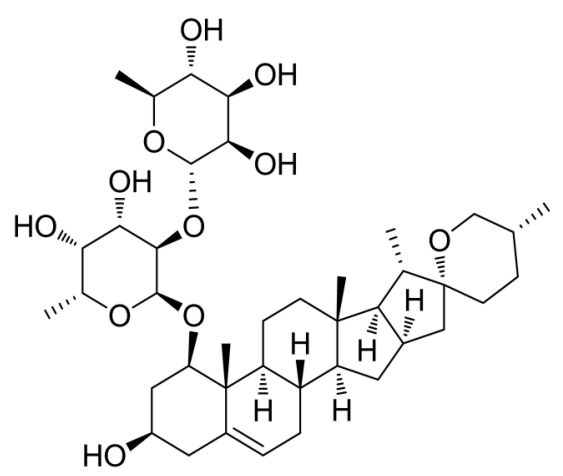

Ophiopogonin B

FIGURE 3 | Chemical structures of components isolated from TCMs with inhibitory effects on PI3K/AKT pathway. 
phosphor-mTOR as well as phospho- p70S6K1. The cleavage of PARP and conversion of LC3 I to LC3 II is consistent with the change of PI3K/Akt/mTOR/p70S6K1 activity. $\beta$-Elemen can induce G2/M phase arrest and apoptotic cell death in nonsmall lung cancer cells with activation of caspases $-9,-3$, and 7 (Wang et al., 2005). $\beta$-Elemen promotes apoptosis through inhibiting the expression of Bcl-2 and survivin in MCF-7 human breast cancer cells ( $\mathrm{Hu}$ et al., 2004). In addition, $\beta$-Elemen can suppress the expressions of VEGF, basic fibroblast growth factor (bFGF), and epidermal growth factor (EGF), and exhibit anticancer ability on laryngeal cancer cells both in vitro and in vivo (Tao et al., 2005, 2006). $\beta$-Elemenal was a primary metabolite in bile of rat after $\beta$-Elemen intravenous administration. A sensitive gas chromatographic-mass spectrometric assay was developed to determine the level of $\beta$-Elemen and $\beta$-Elemenal in human plasma (Chen et al., 2009). The peak plasma concentration (Cmax) and area under curve (AUC) of $\beta$-Elemen were prone to increase in proportion to the dose, but there were no significant differences among $\mathrm{Cl}$ values in the range of dosages. Moreover, no $\beta$-Elemenal was detected in plasma, and there was no other obvious homologous fragment elsewhere, which indicated that $\beta$ Elemen may be mainly decomposed into some small hydrophilic metabolites. Further investigations are needed to determine the biological process of $\beta$-Elemen in vivo (Chen et al., 2009).

Pogostemon Cablin (Blanco) Benth, commonly known as "Guang-huoxiang" in China, is a TCM herb widely used to treat gastrointestinal diseases in many Asian countries (Chen et al., 2015). Pogostone (Figure 3) is one of the major constituent of Pogostemon cablin, and possesses various bioactivities, such as anti-fungal (Li et al., 2012), anti-bacterial (Peng et al., 2014), pesticidal (Huang et al., 2013), and anti-inflammatory activities (Su et al., 2015). Recent studies have revealed that pogostone exhibited potent anti-proliferative activities against multiple human cancer cell lines, especially on human colorectal cancer cells HCT116 (IC50: $18.7 \pm 1.93 \mu \mathrm{g} / \mathrm{mL}$; Cao et al., 2016). Pogostone significantly inhibited AKT and mTOR phosphorylation in a dose-dependent manner, which contributed to the initiation of autophagy and apoptosis in HCT116 cells (Cao et al., 2016). After treatment of pogostone, a dosedependent increase in the levels of LC3 -II, cleaved caspase3 and caspase- 7 , and a significant decrease in pro-caspase- 3 levels were observed in HCT116 cells. Pogostone also inhibited the growth of HCT116 tumor, and reduced the tumor volume significantly with well tolerated by the host in vivo. Pogostone may be developed as a promising drug in the treatment of human colorectal cancer. The preclinical pharmacokinetic investigation of pogostone has been performed in rats after intravenous and oral administration (Chen H. et al., 2013). The results showed that the blood concentration of pogostone appeared to increase nonproportionally between 5 and $20 \mathrm{mg} / \mathrm{kg}$ under the intravenous route (Chen H. et al., 2013).

Stellera chamaejasme $L$. is used to treat skin ulcer and abdominal distension in TCM. Chamaejasmine (Figure 3), a flavone compound isolated from Stellera chamaejasme $L$, displays potent cytotoxicity in multiple cancer cell lines, including human lung cancer A549 cells, and human breast cancer MDA-MB231 cells (Yu et al., 2011; Zhang T. et al., 2013; Yang et al.,
2015). Recent study showed that chamaejasmine could induce apoptosis in HeLa cervical cancer cells, mediated through PI3K/Akt signaling cascades (Qiang and Li, 2017). Treatment of chamaejasmine inactivates AKT to trigger apoptosis in human hep-2 larynx carcinoma cells (Wang et al., 2011b).

Polygonum cuspidatum is believed to possess the effects of dissipating blood stasis and pain relief. Resveratrol 3,4,5trihydroxystilbene, (Figure 3), a polyphenol compound, is isolated and extracted from $P$. cuspidatum with broad bioactivity including anti-bacterial, anti-inflammatory, anticancer, antihyperlipidemia anti-lipid peroxidation and pro-apoptotic effects (Piotrowska et al., 2012; Kucinska et al., 2014). Resveratrol inhibited PI3K and Akt phosphorylations, and subsequently triggered the dephosphorylation of glycogen synthase kinase 3 beta (GSK3 $\beta$ ), which resulted in cyclin D1 degradation and eventually cell cycle arrest and apoptosis in MGC803 human gastric cancer cells (Jing et al., 2016). Furthermore, resveratrol can inhibit the invasion and metastasis of colorectal cancer cells through metastasis associated lung adenocarcinoma transcript 1 (MALAT1) mediated Wnt/ $\beta$-catenin signal pathway (Ji et al., 2013). However, the water solubility of resveratrol was very poor with approximately $0.03 \mathrm{mg} / \mathrm{mL}$ (Vian et al., 2005). In vivo pharmacokinetic study confirmed that the oral bioavailability of resveratrol approaches zero, although administrated with relatively high concentrations of the compounds (Wenzel and Somoza, 2005). Therefore, it is important to enhance the bioavailability of resveratrol, which is considered as the main challenge in successfully applying resveratrol in clinical and health-promoting interventions (Chang et al., 2016).

Ophiopogonin B (OP-B, Figure 3) is a bioactive component of Radix Ophiopogon Japonicus, which is often used in TCM to treat pulmonary disease (Wang Y. H. et al., 2011). OP-B can significantly decrease cell viability in a panel of NSCLC cell lines. OP-B inhibited the PI3K/Akt/mTOR/p70S6K signaling pathway, suppressed p-AKT at both Ser308 and Thr473 and induced autophagy in NCI-H157 and $\mathrm{H} 460$ human lung cancer cells (Chen M. et al., 2013). As a prospective inhibitor of AKT/mTOR, OP-B can also exhibit autophagy-dependent antitumor effects via repression $\mathrm{AKT} / \mathrm{mTOR}$ signaling pathway in human cervical cancer HeLa cells (Xu et al., 2013). OP-B can induce autophagy and apoptosis in A549 human lung cancer cells both in vitro and in vivo (Chen et al., 2016). Moreover, OP-B significantly decreases cell proliferation and induces apoptosis in SGC-7901 human gastric cancer cells via triggering the JNK1/2 and ERK1/2 signaling pathways (Zhang et al., 2016).

\section{COMPONENTS ISOLATED FROM TCMS THAT TARGET EPIDERMAL GROWTH FACTOR RECEPTOR (EGFR)}

EGFR (also known as erbB1 or HER1) belongs to the family of tyrosine kinase receptors that include erbB2 (Neu, HER2), erbB3 (HER3), and erbB4 (HER4). EGFR once combined with EGF can promote the related genes in the cell nucleus, leading to cell proliferation. EGFR is commonly highly expressed in a variety of malignant tumors (Nakao and Fusetani, 2007), and the abnormal 
activation of EGFR is closely correlated with tumor cell biology, acting as an indicator of poor prognosis for the patients with cancer.

The root of Panax ginseng C. A. Mey (Gingsheng) is believed to possess the activity of nourishing vitality and is widely used in China for patients with poor health condition. Ginsenoside Rg3 (GS-Rg3, Figure 4) is one of the active ingredients in Ginsheng with significant antitumor activity. It is also the main component of Shenyi capsule, the first drug used for controlling the metastasis and recurrence of cancer patients in China. GSRg3 shows antitumor effects in a variety of cancers such as gastric, lung, colon, breast, and liver cancers etc. (Lu et al., 2008; He et al., 2011). GS-Rg3 displays various anticancer activities including inhibiting tumor growth, invasion and metastasis, and suppressing angiogenesis in tumor tissues and improving immunity. Synergistic anticancer effects are found when it combined with chemotherapeutic agents (Keum et al., 2003). GS-Rg3 inhibited epithelial-mesenchymal transition (EMT) and invasion of lung cancer by down-regulating fucosyltransferase 4 (FUT4) mediated EGFR inactivation and blocking MAPK and NF- $\mathrm{B}$ signal pathways (Shan et al., 2015; Tian et al., 2016). GSRg3 reduced the expressions of EGFR and pEGFR in MCF-7 breast cancer cells in a dose-dependent manner, suggesting that GS-Rg3 inhibits the tumor growth by targeting EGFR and its down- stream signal transduction pathways (Wang et al., 2008). GS-Rg3 is also an inhibitor of VEGF and bFGF; significantly decreasing the expression of these angiogenesis factors in human A549 lung cancer and human umbilical vein endothelial cells (HUVEC) (Chen et al., 2005). In vitro as well as in vivo study have been carried out to determine the blood level of GS-Rg3 in rat plasma and its major metabolites using an HPLC/Q/TOF analytical approach. GS-Rg3 has an average half-life of $18.5 \mathrm{~min}$ after intravenous administration dosed at $5 \mathrm{mg} / \mathrm{kg}$, whereas it was not detected in rat plasma after oral administration at 100 $\mathrm{mg} / \mathrm{kg}$ (Qian et al., 2005). GS-Rg3 was metabolized to ginsenoside Rh2 and protopanaxadiols (PPD) when anaerobically incubated with human fecal microflora, and the deglycosylated metabolites display activities comparable to or higher than that of GSRg3 (Xie et al., 2005). However, GS-Rg3 has poor solubility and oral bioavailability, which limits its clinical application. Recently, a derivative of the compound, 20(S)-ginsenoside Rg3, was designed and developed as a new drug. Pharmacokinetics has been studied in healthy volunteers in China (Zhao et al., 2016). 20(S)-ginsenoside $\mathrm{Rg} 3$ was generally well tolerated, and exhibited a pharmacokinetic profile suitable for once-every-2-days dosing regimen (Zhao et al., 2016).

Epimedium koreanum Nakai is believed to possess the effects of nourishing Yin and strengthening Yang, promoting blood circulation. Icariside II (Figure 4), a flavonoidglycoside compound, is isolated from the stems and leaves of epimedium koreanum Nakai (Aramwit and Wirotsaengthong, 2012). Studies have shown that icariside II exhibited potent cytotoxicity against a broad spectrum of human cancer cells through various pathways (Kang et al., 2012; Wu et al., 2012). Icariside II displays significant antitumor activity against A431 human epidermoid carcinoma cells in vitro and in mice bearing osteosarcoma sarcoma-180 in vivo by suppressing the phosphorylation of
EGFR, down-regulating EGFR downstream signal PI3K/AKT and Raf/MEK/ERK as well as mTOR pathways in these cancer cells (Wu et al., 2013b; Geng et al., 2014). Icariside II metabolites in rats were analyzed using an ultra-performance liquid chromategraphy/quadrupole- time-of-flight mass spectrometry method. The results showed that the metabolized mainly via desugarisation, dehydrogenation, hydrogenation, hydroxylation, demethylation, glucuronidation, dehydration, and glycosylation pathways in vivo. Specific hydrolysis of 7-O glucoside in the gut lumen and glucuronic acid conjugation in the liver was considered as the main physiologic processes of icariside II (Sun et al., 2014).

The root of Platycodon grandiflorum (Companulaceae) has been extensively used to treat several types of chronic inflammatory diseases in TCM (Shin et al., 2002). Platycodin $\mathrm{D}$ (PD, Figure 4), one of the major saponin components contained in the herb is reported to display antitumor effect on several cancer cell lines (Chun et al., 2013). EGFR/PI3K/AKT pathway plays a critical role in PD induced cell apoptosis and PD downregulates the expression of EGFR in MDA-MB-231 breast cancer cells subsequently leading to the inhibition of the PI3K/AKT and MAPK pathways (Chun and Kim, 2013). Additionally, PD could induce apoptosis and trigger ERK- and JNK-mediated autophagy in human hepatocellular carcinoma BEL-7402 cells (Li T. et al., 2015).

The seed of Myristica fragrans Houtt (Nutmeg) is used to treat diarrhea and ep-igastric pain in TCM. Recent study showed that one of the components myrislignan (Figure 4) isolated from nutmeg, displayed potent anticancer activity against A549 lung cancer cells both in vitro and in vivo (Lu et al., 2016). The effects of myrislignan on apoptosis and cell proliferation are mediated by activation of MAPK and inhibition of EGFR signal pathway.

Peganum harmala $L$. is used to treat cancer in TCMs and Uygur medicine. A novel compound called $3 \alpha$-acetoxy-27hydroxyolean-12-en-28-oic acid methyl ester (OA, Figure 4) was isolated from the herb (Wang et al., 2016). OA possesses potent anticancer activity against NSCLC via inhibiting the activation of EGFR and its downstream signals. Guo et al. developed a model to identify the ERBB3 inhibitors from natural products and TCMs. Several compounds with anticancer activity were identified; among them, VS1 (Figure 4) is the most promising component with $\mathrm{IC}_{50}$ value of $269 \mu \mathrm{M}$ against A549 lung cancer cells (Guo et al., 2016).

\section{CONCLUSIONS}

The discussed components here are isolated from TCMs and their modes of actions are summarized in Table 1. However, it should be kept in mind that numerous components from TCMs display antitumor activity via multiple targets. Most components discussed above show pro-apoptotic activity mediated by activation of caspases and downregulation of mitochondrial antiapoptotic proteins.

In recent years, TCM has gained increasing acceptance and attention worldwide, and is recognized as a rich source for drug discovery and development. TCM is widely used in China to 


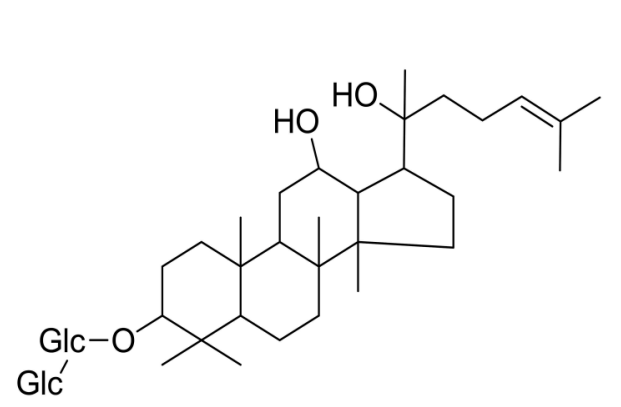

GS-Rg3<smiles>COc1ccc(-c2oc3c(CC=C(C)C)c(O)cc(O)c3c(=O)c2OC2OC3OC2C(O)C(O)C3O)cc1</smiles>

Icariside II

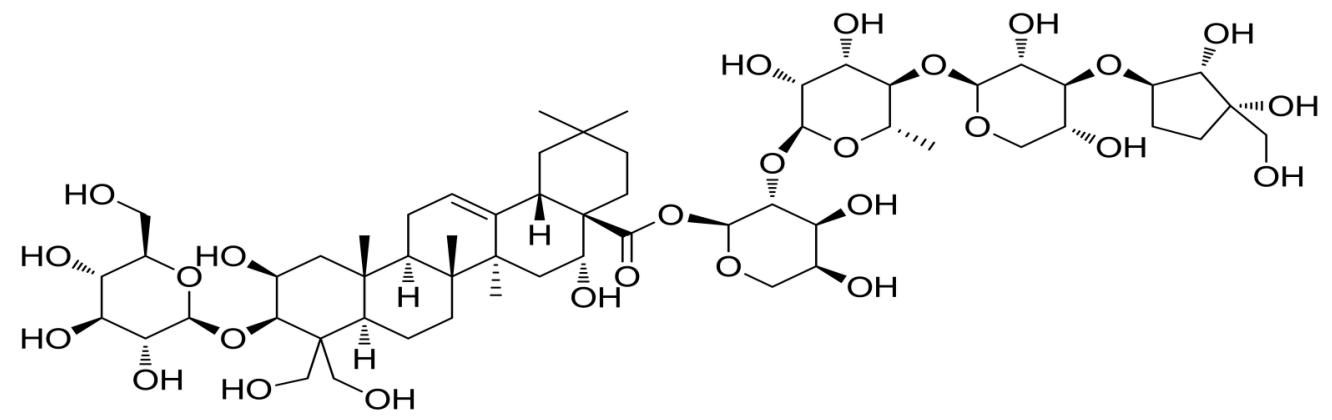

\section{Platycodin D}<smiles>C=CCc1cc(OC)c(O[C@H](C)[C@H](O)c2ccc(O)c(OC)c2)c(OC)c1</smiles>

myrislignan<smiles>Cc1ccc2c(c1)[C@]1(N[C@H](Cc3c[nH]c4ccccc34)[C@H]3C(=O)N(c4ccc5c(c4)OCCO5)C(=O)[C@@H]31)C(=O)N2</smiles>

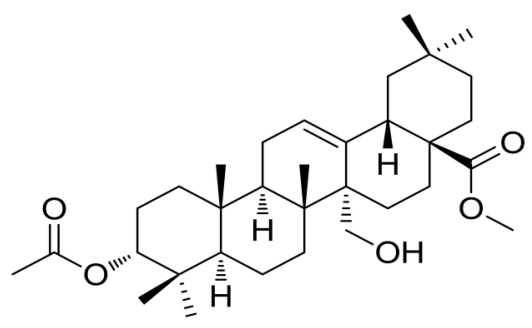

OA

\section{VS1}

FIGURE 4 | Chemical structures of components isolated from TCM that target Epidermal Growth Factor Receptor (EGFR). 
TABLE 1 | A summary of Traditional Chinese Medicines as kinase inhibitors.

\begin{tabular}{|c|c|c|c|c|}
\hline $\begin{array}{l}\text { Name of Anti-tumor } \\
\text { TCMs }\end{array}$ & Sources & Classification & Kinase inhibitors and cell lines & References \\
\hline Curcuma & Curcuma longa $L$. & Polyphenols & $\begin{array}{l}\text { JNK/p38 MAPK/ERK HCT-116, THP-1, } \\
\text { CNE1, CNE2, and HepG2 cells }\end{array}$ & $\begin{array}{l}\text { Collett and Campbell, } \\
\text { 2004; Chintana et al., } \\
\text { 2011; Yang et al., 2012; } \\
\text { Wang et al., } 2013\end{array}$ \\
\hline Celastrol & Tripterygium wilfordii Hook. $f$. & Triterpene & $\begin{array}{l}\text { JNK HOS, MG-63, U-2OS, and Saos-2 } \\
\text { cells }\end{array}$ & Li H. Y. et al., 2015 \\
\hline Chelerythrine & Chelidonium majus L. & $\begin{array}{l}\text { Benzophen anthridine } \\
\text { alkaloid }\end{array}$ & $\begin{array}{l}\text { JNK/p38 MAPK/ERK Hela, HOS, and } \\
\text { U-2OS cells }\end{array}$ & $\begin{array}{l}\text { Yu et al., 2000; Yang } \\
\text { et al., } 2008\end{array}$ \\
\hline Emodin & Rheum palmatum L. & Anthraquinone & $\begin{array}{l}\text { ERK/p38 MAPK SMMC-7721, SW480, } \\
\text { and SW620 cells }\end{array}$ & $\begin{array}{l}\text { Liu et al., 2015; Lin et al., } \\
2016\end{array}$ \\
\hline Tubeimoside-1 & $\begin{array}{l}\text { Bolbostemma paniculatum } \\
\text { Franquet }\end{array}$ & Triterpenoid saponin & $\begin{array}{l}\text { JNK/p38 MAPK/ERK DU145, A549, PC9 } \\
\text { A2780/DDP, SKOV-3. and HepG2 cells }\end{array}$ & $\begin{array}{l}\text { Liu H. Z. et al., 2011; Yin } \\
\text { et al., 2011; Chen W. J. } \\
\text { et al., 2012; Hao et al., } \\
\text { 2015; Yang et al., } 2016\end{array}$ \\
\hline$\beta$-eudesmol & Atractylodes lancea rhizome & Sesquiterpenol & JNK HL60 cell & Li Y. et al., 2013 \\
\hline Hinesol & Atractylodes lancea rhizome & Sesquiterpenol & JNK/ERK HL60 cell & Masuda et al., 2015 \\
\hline Isoquercitrin & Bidens bipinnata $L$. & Favonoid & JNK/p38 MAPK/ERK HepG2 cell & Huang et al., 2014 \\
\hline PYDDT & Echinops grijsii & $\begin{array}{l}\text { Alkynol group- } \\
\text { substituted thiophene }\end{array}$ & JNK SW620 cell & Xu et al., 2015 \\
\hline Tatariside G & Fagopyrum tataricum (L.) Gaertn & $\begin{array}{l}\text { Phenylpropan- oid } \\
\text { glycosides }\end{array}$ & JNK/p38 MAPK HeLa cell & Li et al., 2014 \\
\hline SYUNZ-16 & Arnebia euchroma roots & $\begin{array}{l}\text { b,b- } \\
\text { dimethylacrylalkannin }\end{array}$ & AKT Hep3B and GLC-82 cells & Deng et al., 2010 \\
\hline Arenobufagin & $\begin{array}{l}\text { Bufo gargarizans Cantor or Bufo } \\
\text { melanostictus Suhneider }\end{array}$ & C24 steroids & $\begin{array}{l}\text { PI3K/Akt/mTOR HepG2 and HepG2/ } \\
\text { ADM cells }\end{array}$ & Zhang D. M. et al., 2013 \\
\hline Tetrandrine & Radix Stephaniae tetrandrae & $\begin{array}{l}\text { Bisbenzylisoquinoline } \\
\text { alkaloid }\end{array}$ & $\begin{array}{l}\text { ERK and PI3K/AKT HT-29, Huh7, HepG2 } \\
\text { and BEL7402 cells }\end{array}$ & $\begin{array}{l}\text { Chen et al., 2008; Liu C. } \\
\text { Y. et al., } 2011\end{array}$ \\
\hline$\beta$-Elemene & Rhizomazedo- ariae & Terpene & $\begin{array}{l}\text { PI3K/Akt/mTOR MGC803 and SGC7- } \\
\text { 901cells }\end{array}$ & $\begin{array}{l}\text { Liu C. Y. et al., 2011; Liu } \\
\text { J. et al., } 2011\end{array}$ \\
\hline Pogostone & $\begin{array}{l}\text { Pogostemon Cablin (Blanco) } \\
\text { Benth }\end{array}$ & Ketone & PI3K/Akt/mTOR HCT116 cell & Cao et al., 2016 \\
\hline Chamaejasmine & Stellera chamaejasme L. & Flavonoid & PI3K/Akt HeLa and HEp-2 cells. & $\begin{array}{l}\text { Wang et al., 2011b; Qiang } \\
\text { and Li, } 2017\end{array}$ \\
\hline Resveratrol & Polygonum cuspidatum & Polyphenol & PI3K/Akt MGC803 cell & Jing et al., 2016 \\
\hline Ophiopogonin-B & Radix Ophiopogon Japonicus & Saponin & $\begin{array}{l}\text { PI3K/Akt/mTOR NCl-H157, H460 and } \\
\text { HeLa cells }\end{array}$ & $\begin{array}{l}\text { Chen M. et al., 2013; Xu } \\
\text { et al., } 2013\end{array}$ \\
\hline Ginsenoside Rg3 & Ginsheng & Saponin & $\begin{array}{l}\text { EGFR and VEGF A549, H1299, H358, } \\
\text { MCF-7 and HUVEC304 cells }\end{array}$ & $\begin{array}{l}\text { Chen et al., 2005; Wang } \\
\text { et al., 2008; Tian et al., } \\
2016\end{array}$ \\
\hline Icariside I| & Yin Yanghuo Horny Goat Weed & Flavonoid & EGFR A431 cell & $\begin{array}{l}\text { Wu et al., 2013b; Geng } \\
\text { et al., } 2014\end{array}$ \\
\hline Platycodin D & Platycodon grandiflorum & Saponin & EGFR MDA-MB-231 cell & Chun and Kim, 2013 \\
\hline Myrislignan & Myristica fragrans Houtt & Lignans & EGFR A549 cell & Lu et al., 2016 \\
\hline OA & Peganum harmala $L$. & Triterpene & EGFR A549 cell & Wang et al., 2016 \\
\hline VS1 & & Heterocycle & ERBB3 A549 cell & Guo et al., 2016 \\
\hline
\end{tabular}

reduce the side effects of chemotherapeutic drugs and improve the outcome of conventional treatment. It should emphasize that in some cases, the mixed extracts of TCM display more potent antitumor effects than the single individual component and exhibited synergistic effects with most TCM preparation. Our recent study revealed that the crude extract of clove bud can induce cell death via apoptotic pathway and inhibit the growth of cancer cells both in vitro and in vivo. However, the isolated bioactive component, Oleanolic acid, displays much weaker antitumor activity compared to the crude extract in the nude mouse models of xenografted human tumors, suggesting synergistic antitumor effects exist among the components in the extract of clove bud (Liu et al., 2014).

Although, chemotherapy is acknowledged as one of the most effective therapeutic methods for cancers in late stage, it faces serious side effects and drug resistance. TCM provide 
a novel strategy for cancer therapy. However, the underlying mechanisms of most TCM have not been elucidated yet. On the other hands, numerous components isolated from TCMs possess poor bioavailability; novel approaches, including chemical modification, nanotechnology etc. should be employed to improve their efficacy in vivo. It is likely that the efficacy of TCM in cancer treatment may lead to novel strategies in fight against various cancers.

\section{AUTHOR CONTRIBUTIONS}

ML, GZ are Equal contributors and co-first authors. ML, GZ, YZ, and XFL consulted literature about Targeting protein kinases

\section{REFERENCES}

Aramwit, P., and Wirotsaengthong, S. (2012). Overview of commonly used Chinese herbs. J. Med. Plants Res. 6, 4505-4521. doi: 10.5897/JMPR11.481

Banerjee, M., Singh, P., and Panda, D. (2010). Curcumin suppresses the dynamic instability of microtubules, activates the mitotic checkpoint and induces apoptosis in MCF-7 cells. FEBS J. 277, 3437-3448. doi: 10.1111/j.1742-4658.2010.07750.x

Bosch, F. X., Ribes, J., Díaz, M., and Cléries, R. (2004). Primary liver cancer: worldwide incidence and trends. Gastroenterology. 127, S5-S16. doi: 10.1053/j.gastro.2004.09.011

Brown, V. I., Fang, J., Alcorn, K., Barr, R., Kim, J. M., Wasserman, R.,et al. (2003). Rapamycin is active against B-precursor leukemia in vitro and in vivo, an effect that is modulated by IL-7-mediated signaling. Proc. Natl. Acad. Sci. U.S.A. 100, 15113-15118. doi: 10.1073/pnas.2436348100

Brugge, J., Hung, M. C., and Mills, G. B. (2007). A new mutational AKTivation in the PI3K pathway. Cancer Cell 12, 104-107. doi: 10.1016/j.ccr.2007.07.014

Cao, Z. X., Yang, Y. T., Yu, S., Li, Y. Z., Wang, W. M., Huang, J., et al. (2016). Pogostone induces autophagy and apoptosis involving PI3K/Akt/mTOR axis in human colorectal carcinoma HCT116 cells. J. Ethnopharmacol. 8741, 30453-30456. doi: 10.1016/j.jep.2016.07.028

Chang, C. W., Wong, C. Y., Wu, Y. T., and Hsu, M. C. (2016). Development of a Solid Dispersion System for Improving the Oral Bioavailability of Resveratrol in Rats. Eur. J. Drug Metab. Pharmacokinet. doi: 10.1007/s13318-016-0339-0. [Epub ahead of print].

Chang, L., and Karin, M. (2001). Mammalian MAP kinase signalling cascades. Nature 410, 37-40. doi: 10.1038/35065000

Chen, G., Hu, X., Zhang, W., Xu, N., Wang, F. Q., Jia, J., et al. (2012). Mammalian target of rapamycin regulates isoliquiritigenin-induced autophagic and apoptotic cell death in adenoid cystic carcinoma cells. Apoptosis 17, 90-101. doi: 10.1007/s10495-011-0658-1

Chen, H., Liao, H., Liu, Y., Zheng, Y., Wu, X., Su, Z., et al. (2015). Protective effects of pogostone from Pogostemonis Herba against ethanol- induced gastric ulcer in rats. Fitoterapia 100, 110-117. doi: 10.1016/j.fitote.2014.11.017

Chen, H., Li, Y., Wu, X., Li, C., Li, Q., Qin, Z., et al. (2013). LCMS/MS determination of pogostone in rat plasma and its application in pharmacokinetic studies. Biomed. Chromatogr. 27, 1092-1099. doi: $10.1002 /$ bmc.2897

Chen, M., Du, Y., Qui, M., Wang, M., Chen, K., Huang, Z., et al. (2013). Ophiopogonin B-induced autophagy in non-small cell lung cancer cells via inhibition of the PI3K/Akt signaling pathway. Oncol. Rep. 29, 430-436. doi: 10.3892/or.2012.2131

Chen, M., Guo, Y., Zhao, R., Wang, X., Jiang, M., Fu, H., et al. (2016). Ophiopogonin B induces apoptosis, mitotic catastrophe and autophagy in A549 cells. Int. J. Oncol. 49, 316-324. doi: 10.3892/ijo.2016.3514

Chen, M. W., Ni, L., Zhao, X. G., and Niu, X. Y. (2005). The inhibition of 20 (R)-g insenoside $\mathrm{Rg} 3$ on the expressions of angiogenesis factors proteins in human lung adenocarcinoma cell line A549 and HUVEC304 cell. Zhongguo Zhong Yao Za Zhi. 30, 357-360. Available online at: http://www.cnki.net/KCMS/detail/ with components from Traditional Chinese Medicine. ML, GZ wrote the review. XKL, SC edited and revised the manuscript critically for important intellectual content.

\section{ACKNOWLEDGMENTS}

This work was supported by 863 High Technology Project (2014AA093503) and National innovative drug development projects of (2014ZX- 09102043-001). The study was also supported in part by National Foundation of Natural Sci. of China (81302906, 81273550, and 41306157) and the Distinguished Professor Research Startup Funding (SC and XKL) from Southwest Medical University.

detail.aspx?QueryID=1\&CurRec=1\&filename=ZGZY200505009\&dbname= CJFD2005\&dbcode

Chen, W. J., Yu, C., Yang, Z., He, J. L., Yin, J., Liu, H. Z., et al. (2012). Tubeimoside1 induces G2/M phase arrest and apoptosis in SKOV-3 cells through increase of intracellular $\mathrm{Ca} 2+$ and caspase-dependent signaling pathways. Int. J. Oncol. 40, 535-543. doi: 10.3892/ijo.2011.1218

Chen, X. L., Ren, K. H., He, H. W., and Shao, R. G. (2008). Involvement of $\mathrm{PI} 3 \mathrm{~K} / \mathrm{AKT} / \mathrm{GSK} 3$ beta pathway in tetrandrine-induced G1 arrest and apoptosis. Cancer Biol. Ther. 7, 1073-1078. doi: 10.4161/cbt.7.7.6142

Chen, Z., Song,Y., Che, J., Liu, X., Ning, Y., Shan, C., et al. (2009). Validation of a sensitive gas chromatographic-mass spectrometric method for the simultaneous determination of $\beta$-elemene and $\beta$-elemenal in human plasma. J. Chromatogr. B. 877, 408-414. doi: 10.1016/j.jchromb.2008.12.038

Cheng, A. L., Hsu, C. H., Lin, J. K., Hsu, M. M., Ho, Y. F., Shen, T. S., et al. (2001). Phase I clinical trial of curcumin, a chemopreventive agent, in patients with high-risk or pre-malignant lesions. Anticancer Res. 21, 2895-2900.

Cheng, C. Y., Lin, Y. H., and Su, C. C. (2010). Curcumin inhibits the ptoliferation of human hepatocellular carcinoma 55 cells by inducing endoplasmic reticulum stress and mitochondrial dysfunction. Int. J. Mol. Med. 26, 637-638. doi: 10.3892/ijmm_00000513

Chintana, P. Y., Wirachwong, P., Suksamrarn, A., and Patumraj, S. (2011). Downregulation of p-ERK1/2 and p-AKT expression by curcumin and tetrahydrocurcumin in hepatocellular carcinoma-induced tumors in nude mice. Asian Biomedicine. 5, 345-352. doi: 10.5372/1905-7415. 0503.045

Chmura, S. J., Dolan, M. E., Cha, A., Mauceri, H. J., Kufe, D. W., and Weichselbaum, R. R. (2000). In vitro and in vivo activity of protein kinase C inhibitor chelerythrine chloride induces tumor cell toxicity and growth delay in vivo. Clin Cancer Res. 6, 737-742.

Chun, J., Ha, I. J., and Kim, Y. S. (2013). Antiproliferative and apoptotic activities of triterpenoid saponins from the roots of Platycodon grandiflorum and their structure-activity relationships. Planta Med. 79, 639-645. doi: 10.1055/s-0032-1328401

Chun, J., and Kim, Y. S. (2013). Platycodin D inhibits migration, invasion, and growth of MDA-MB-231 human breast cancer cells via suppression of EGFR-mediated Akt and MAPK pathways. Chem. Biol. Interact. 205, 212-221. doi: 10.1016/j.cbi.2013.07.002

Collett, G. P., and Campbell, F. C. (2004). Curcumin induces c-jun Nterminal kinase-dependent apoptosis in HCT116 human colon cancer cells. Carcinogenesis 25, 2183-2189. doi: 10.1093/carcin/bgh233

Crowell, J. A., Steele, V. E., and Fay, J. R. (2007). Targeting the AKT protein kinase for cancer chemoprevention. Mol. Cancer Ther. 6, 2139-2148. doi: 10.1158/1535-7163.MCT-07-0120

Deng, R., Tang, J., Xie, B. F., Feng, G. K., Huang, Y. H., Liu, Z. C., et al. (2010). SYUNZ-16, a newly synthesized alkannin derivative, induces tumor cells apoptosis and suppresses tumor growth through inhibition of PKB/AKT kinase activity and blockade of AKT/FOXO signal pathway. Int. J. Cancer. 127, 220-229. doi: 10.1002/ijc.25032 
Dhanasekaran, D. N., and Reddy, E. P. (2008). JNK signaling in apoptosis. Oncogene 27, 6245-6251. doi: 10.1038/onc.2008.301

Feng, G. E., Wang, X. D., and Wang, Y. C. (2003). Advances in studies on medicinal Radix Arnebiae Seu Lithospermi. Chinese Trad. Herbal Drugs 9, 6-10. Available online at: http://xueshu.baidu.com/s?wd=paperuri\%3A \%2881ad236a27728311b27976433daffc6f\%29\&filter

Ferré, F., Palmeri, A., and Helmer-Citterich, M. (2014). Computational methods for analysis and inference of kinase/inhibitor relationships. Front. Genet. 5:196. doi: 10.3389/fgene.2014.00196

Geng, Y. D., Yang, L., Zhang, C., and Kong, L. Y. (2014). Blockade of epidermal growth factor receptor/mammalian target of rapamycin pathway by Icariside II results in reduced cell proliferation of osteosarcoma cells. Food Chem. Toxicol. 73, 7-16. doi: 10.1016/j.fct.2014.08.002

Goldstein, D. M., Gray, N. S., and Zarrinkar, P. P. (2008). High-throughput kinase profiling as a platform for drug discovery. Nat. Rev. Drug Discov. 7, 391-397. doi: $10.1038 / \mathrm{nrd} 2541$

Gong, Z. P., Chn, T., Deng, L. R., and Hu, Y. Q. (2010). Research progress on the antitumor clinical application of cinobufacin injection combined with chemotherapy. Anhui. Med. Pharm. J. 14, 12-14. Available online at: http://xueshu.baidu.com/s?wd=paperuri\%3A \%28b5fb394876df1eba1989810749b9ffba\%29\&filter

Guo, R., Zhang, Y., Li, X., Song, X., Li, D., and Zhao, Y. (2016). Discovery of ERBB3 inhibitors for non-small cell lung cancer (NSCLC) via virtual screening. J. Mol. Model. 22:135. doi: 10.1007/s00894-016-3007-Z

Hao, W., Wang, S., and Zhou, Z. (2015). Tubeimoside-1 (TBMS1) inhibits lung cancer cell growth and induces cells apoptosis through activation of MAPKJNK pathway. Int. J. Clin. Exp. Pathol. 8, 12075-12083.

He, B. C., Gao, J. L., Luo, X., Luo, J., Shen, J., Wang, L., et al. (2011). Ginsenoside $\mathrm{Rg} 3$ inhibits colorectal tumor growth through the down-regulation of Wnt/ $\beta$ catenin signaling. Int. J. Oncol. 38, 437-445. doi: 10.3892/ijo.2010.858

Hennessy, B. T., Smith, D. L., Ram, P. T., Lu, Y., and Mills, G. B. (2005). Exploiting the PI3K/AKT pathway for cancer drug discovery. Nat. Rev. Drug Discov. 4, 988-1004. doi: 10.1038/nrd1902

Hu, J., Jin, W., and Yang, P. M. (2004).Reversal of resistance to adriamycin in human breast cancer cell line MCF-7/ADM by beta-elemene. Chin. J. Oncol. 26, 268-270. Available online at: http://www.cnki.net/KCMS/detail/detail.aspx? QueryID $=17 \&$ CurRec $=14 \&$ filename $=$ ZHZL200405005\&dbname $=$ CJFD2004\& dbcodekoUKaID8j8gFw

Hu, Y., Yu, Z., Yang, Z. J., Zhu, G., and Fong, W. (2011). Comprehensive chemical analysis of Toad venom by using liquid chromatography/electrospray ionization tandem mass spec-trometry. J. Pharm. Biomed. Anal. 56, 210-220. doi: 10.1016/j.jpba.2011.05.014

Huang, G., Tang, B., Tang, K., Dong, X., Deng, J., Liao, L., et al. (2014). Isoquercitrin inhibits the progression of liver cancer in vivo and in vitro via the MAPK signalling pathway. Oncol. Rep. 31, 2377-2384. doi: 10.3892/or.2014.3099

Huang, S. H., Xian, J. D., Kong, S. Z., Li, Y. C., Xie, J. H., Lin, J., et al. (2013). Insecticidal activity of pogostone against Spodoptera litura and Spodoptera exigua (Lepidoptera: Noctuidae). Pest Manag. Sci. 70, 510-516. doi: $10.1002 /$ ps.3635

Huang, Y., Zhou, Y., Fan, Y., and Zhou, D. (2008). Celastrol inhibits the growth of human gliomaxenografts in nude mice through suppressing VEGFR expression. Cancer Lett. 264, 101-106. doi: 10.1016/j.canlet.2008. 01.043

Ireson, C. R., Jones, D. J., Orr, S., Coughtrie, M. W., Boocock, D. J., Williams, M. L., et al. (2002). Metabolism of the cancer chemopreventive agent curcumin in human and rat intestine. Cancer Epidemiol. Biomark Prev. 11, 105-111.

Ji, Q., Liu, X., Fu, X., Zhang, L., Sui, H., Zhou, L., et al. (2013). Resveratrol inhibits invasion and metastasis of colorectal cancer cells via MALAT1 mediated Wnt/B-catenin signal pathway. PLoS ONE 8:e78700. doi: 10.1371/journal.pone.0078700

Jia, G., Wang, Q., Wang, R., Deng, D., Xue, L., Shao, N., et al. (2015). Tubeimoside-1induces glioma apoptosis through regulation of $\mathrm{Bax} / \mathrm{Bcl}-2$ and the ROS/Cytochrome C/Caspase-3 pathway. Onco. Targets. Ther. 8, 303-311. doi: 10.2147/OTT.S76063

Jiang, X. H., Yang, J. Q., Li, N., Wang, H., and Zhou, Q. X. (2011).The pharmacokinetical study of plant alkaloid tetrandrine with a simple HPLC method in rabbits. Fitoterapia 82, 878-882. doi: 10.1016/j.fitote.2011. 04.014
Jin, W., Sh,i, Q., Hong, C., Cheng, Y., Ma, Z., and Qu, H. (2008). Cytotoxic properties of thiophenes from Echinops grijissi Hance. Phytomedicine 15, 768-774. doi: 10.1016/j.phymed.2007.10.007

Jing, X., Cheng, W., Wang, S., Li, P., and He, L. (2016). Resveratrol induces cell cycle arrest in human gastric cancer MGC803 cells via the PTEN regulated PI3K/Akt signaling pathway. Oncol. Rep. 35, 472-478. doi: 10.3892/or.2015.4384

Johnson, S. M., Gulhati, P., Arrieta, I., Wang, X., Uchida, T., Gao, T., et al. (2009). Curcumin inhibits proliferation of colorectal carcinoma by modulating Akt/ mTOR signaling. Anticancer Res. 29, 3185-3190.

Kang, S. H., Jeong, S. J., Kim, S. H., Kim, J. H., Jung, J. H., Koh, W., et al. (2012). Icariside II induces apoptosis in U937 acute myeloid leukemia cells: role of inactivation of STAT3-related signaling. PLoS ONE 7:e28706. doi: 10.1371/journal.pone.0028706

Kannaiyan, R., Manu, K. A., Chen, L., Li, F., Rajendran, P., Subramaniam, A., et al. (2011). Celastrol inhibits tumor cell proliferation and promotes apoptosis through the activation of $\mathrm{c}$-Jun $\mathrm{N}$-terminal kinase and suppression of PI3 K/Akt signaling pathways. Apoptosis 16, 1028-1041. doi: 10.1007/s10495-0110629-6

Kannan-Thulasiraman, P., Katsoulidis, E., Tallman, M. S., Arthur, J. S., and Platanias, L. C. (2006). Activation of the mitogen- and stressactivated kinase 1 by arsenic -trioxide. J. Biol. Chem. 281, 22446-22452. doi: 10.1074/jbc.M603111200

Karki, R., Park, C. H., and Kim, D. W. (2013). Extract of buckwheat sprouts scavenges oxidation and inhibits pro-inflammatory mediators in lipopolysaccharide-stimulated macrophages (RAW264.7). J. Integr. Med. 11, 246-252. doi: 10.3736/jintegrmed2013036

Keum, Y. S., Han, S. S., Chun, K. S., Park, K. K., Park, J. H., Lee, S. K., et al. (2003). Inhibitory effects of the ginsenoside Rg3 on phorbol ester-induced cyclooxygenase-2 expression, NF-KB activation and tumor promotion. Mutat. Res. 523-524, 75-85. doi: 10.1016/S0027-5107(02)00323-8

Kucinska, M., Piotrowska, H., Luczak, M. W., Mikula-Pietrasik, J., Ksiazek, K., Wozniak, M., et al. (2014). Effects of hydroxylated resveratrol analogs on oxidative stress and cancer cells death in human acute $\mathrm{T}$ cell leukemia cell line: Prooxidative potential of hydroxylated resveratrol analogs. Chem. Biol. Interact. 209, 96-110. doi: 10.1016/j.cbi.2013.12.009

Lao, C. D., Ruffin, M. T. IV, Normolle, D., Heath, D. D., Murray, S. I., Balley, J. M., et al. (2006). Dose escalation of a curcuminoid formulation. BMC Complement Altern. Med. 6:10. doi: 10.1186/1472-6882-6-10

Lee, J. H., Won, Y. S., Park, K. H., Lee, M. K., Tachibana, H., Yamada, K., et al. (2012). Celast Celastrol inhibits growth and induces apoptotic cell death in melanoma cells via the activation ROS-dependent mitochondrial pathway and the suppression of PI3K/AKT signaling. Apoptosis 17, 1275-1286. doi: 10.1007/s10495-012-0767-5

Li, G., Han, W., Jiang, W., Zhang, D., Ye, W., Chen, X., et al. (2013). Quantitative determination of arenobufagin in rat plasma by ultra fast liquid chromatography-tandem mass spectrometry and its application in a pharmacokinetic study. J. Chromatogr. B. 939, 86-91. doi: 10.1002/bmc.2768

Li, H. Y., Zhang, J., Sun, L. L., Li, B. H., Gao, H. L., Xie, T., et al. (2015). Celastrol induces apoptosis and autophagy via the ROS/JNK signaling pathway in human osteosarcoma cells: an in vitro and in vivo study. Cell Death and Disease. 6:e1604. doi: 10.1038/cddis.2014.543

Li, M., Wu, S., Liu, Z., Zhang, W., Xu, J., Wang, Y., et al. (2013). Arenobufagin, a bufadienolide compound from toad venom, inhibits VEGF-mediated angiogenesis through suppression of VEGFR-2 signaling pathway. Biochem. Pharmacol. 83, 1251-1260. doi: 10.1016/j.bcp.2012.01.023

Li, Q. Q., Wang, G., Zhang, M., Cuff, C. F., Huang, L., and Reed, E. (2009). beta-Elemene, a novel plant-derived antineoplastic agent, increases cisplatin chemosensitivity of lung tumor cells by triggering apoptosis. Oncol. Rep. 22, 161-170. doi: 10.3892/or_00000420

Li, T., Xu, X. H., Tang, Z. H., Wang, Y. F., Leung, C. H., Ma, D. L., et al. (2015). Platycodin D induces apoptosis and triggers ERK- and JNK-mediated autophagy in human hepatocellular carcinoma BEL-7402 cells. Acta Pharmacol. Sin. 36, 1503-1513. doi: 10.1038/aps.2015.99

Li, Y. C., Liang, H. C., Chen, H. M., Tan, L. R., Yi, Y. Y., Qin, Z., et al. (2012). Anti-Candida albicans activity and pharmacokinetics of pogostone isolated from Pogostemonis Herba. Phytomedicine 20, 77-83. doi: $10.1016 /$ j.phymed.2012.08.008 
Li, Y., Li, T., Miao, C., Li, J., Xiao, W., and Ma, E. (2013). $\beta$-Eudesmol induces JNK-dependent apoptosis through the mitochondrial pathway in HL60 cells. Phytother. Res. 27, 338-343. doi: 10.1002/ptr.4727

Li, Y., Wang, S. J., Xia, W., Rahman, K., Zhang, Y., Peng, H., et al. (2014). Effects of tatariside $G$ isolated from fagopyrum tataricum roots on apoptosis in human cervical cancer HeLa cells. Molecules 19, 11145-11159. doi: $10.3390 /$ molecules190811145

Liang, M. J., Zhang, W. D., Zhang, C., Liu, R. H., Shen, Y. H., Li, H. L., et al. (2007). Quantitative determination of the anticancer agent tubeimoside I in rat plasma by liquid chromatography coupled with mass spectrometry. J. Chromatogr. B. 845, 84-89. doi: 10.1016/j.jchromb.2006.07.053

Lim, E. S., Rhee, Y. H., Park, M. K., Shim, B. S., Ahn, K. S., Kang, H., et al. (2007). DMNQ S-64 induces apoptosis via caspase activation and cyclooxygenase-2 inhibition in human nonsmall lung cancer cells. Ann. N.Y. Acad. Sci. 1095, 7-18. doi: 10.1196/annals.1397.002

Lin, B., Hu, C. L., Huang, F., and Han, T. (2011). Research progress on chemical constituents and pharmacological effect of Fagopyrum tataricum. Drugs Clinic. 26, 29-32. Available online at: http://www.cnki.net/KCMS/detail/detail.aspx? QueryID $=16 \&$ CurRec $=13 \&$ filename $=$ GWZW201101006\&dbname $=$ CJFD2011 \&dbcode

Lin, S. P., Chu, P. M., Tsai, S. Y., Wu, M. H., and Hou, Y. C. (2012). Pharmacokinetics and tissue distribution of resveratrol, emodin and their metabolites after intake of Polygonum cuspidatum in rats. J. Ethnopharmacol. 144, 671-676. doi: 10.1016/j.jep.2012.10.009

Lin, S. T., Wang, Y., Xue, Y., Feng, D. C., Xu, Y., and Xu, L. Y. (2008). Tetrandrine suppresses LPS-induced astrocyte activationvia modulating IKKsIkappaBalpha NF-кB signaling pathway. Mol. Cell. Biochem. 315, 41-49 doi: $10.1007 / \mathrm{s} 11010-008-9787-4$

Lin, W., Zhong, M., Yin, H., Chen, Y., Cao, Q., Wang, C., et al. (2016). Emodin induces carcinoma cell apoptosis through MAPK and PI3K/AKT signaling pathways in vitro and in vivo. Oncol. Rep. 36, 961-967. doi: 10.3892/or.2016.4861

Liu, B., Yuan, B., Zhang, L., Mu, W., and Wang, C. (2015). ROS/p38/p53/Puma signaling pathway is involved in emodin-induced apoptosis of human colorectal cancer cells. Int. J. Clin. Exp. Med. 8, 15413-15422.

Liu, C. Y., Gong, K., Mao, X., and Li, W. H. (2011).Tetrandrine induces apoptosis by activating reactive oxygen species and repressing Akt activity in human hepatocellular carcinoma. Int. J. Cancer. 129, 1519-1531. doi: 10.1002/ijc.25817

Liu, H., Schmitz, J. C., Wei, J., Cao, S., Beumer, J. H., Strychor, S., et al. (2014). Clove extract inhibits tumor growth and promotes cell cycle arrest and apoptosis. Oncol. Res. 21, 247-259. doi: 10.3727/096504014X13946388748910

Liu, H. Z., Yu, C., Yang, Z., He, J. L., Chen, W. J., Yin, J., et al. (2011). Tubeimoside I sensitizes cisplatin in cisplatin-resistant human ovarian cancer cells (A2780/DDP) through down-regulation of ERK and up-regulation of p38 signaling pathways. Mol. Med. Rep. 4, 985-992. doi: 10.3892/mmr.2011.513

Liu, J. S., Zhang, D. M., Kurihara, H., and Ye, W. C. (2009). Antitumor effects of toad venom and its active components. J. Int. Pharm. Res. 4, 115-120. doi: 10.13220/j.cnki.jipr.2009.02.004

Liu, J., Zhang, Y., Qu, J., Xu, L., Hou, K., Zhang, J., et al. (2011). b-Elemene-induced autophagy protects human gastric cancer cells from undergoing apoptosis. BMC Cancer 11:183. doi: 10.1186/1471-2407-11-183

Liu, L., Cao, Y., Chen, C., Zhang, X., McNabola, A., Wilkie, D., et al. (2006). Sorafenib blocks the RAF/MEK/ERK pathway, inhibits tumor angiogenesis, and induces tumor cell apoptosis in hepatocellular carcinoma model PLC/PRF/5. Cancer Res. 66, 11851-11858. doi: 10.1158/0008-5472.CAN-06-1377

Liu, W., Feng, Q., Li, Y., Ye, L., Hu, M., and Liu, Z. (2012). Coupling of UDP-glucuronosyltransferases and multidrug resistance- associated proteins is responsible for the intestinal disposition and poor bioavailability of emodin. Toxicol. Appl. Pharmacol. 265, 316-324. doi: 10.1016/j.taap.2012. 08.032

LoPiccolo, J., Granville, C. A., Gills, J. J., and Dennis, P. A. (2007). Targeting Akt in cancer therapy. Anticancer. Drugs 18, 861-874. doi: 10.1097/CAD.0b013e3280cc2c6f

Lu, P., Su, W., Miao, Z. H., Niu, H. R., Liu, J., and Hua, Q. L. (2008). Effect and mechanism of ginsenoside Rg3 on postoperative life span of patients with non-small cell lung cancer. Chin. J. Integr. Med. 14, 33-36. doi: $10.1007 /$ s11655-007-9002-6
Lu, Q., Liu, W., Ding, J., Cai, J., and Duan, W. (2002). Shikonin derivatives: synthesis and inhibition of human telomerase. Bioorg. Med. Chem. Lett. 12, 1375-1378. doi: 10.1016/S0960-894X(02)00158-0

Lu, X., Yang, L., Chen, J., Zhou, J., Tang, X., Zhu, Y., et al. (2016). The action and mechanism of myrisligna on A549 cells in vitro and in vivo. J. Nat. Med. doi: 10.1007/s11418-016-1029-6. [Epub ahead of print].

Ma, L., and Li, W. (2014). Emodin inhibits LOVO colorectal cancer cell proliferation via the regulation of the Bcl-2/Bax ratio and cytochrome c. Exp Ther Med. 8, 1225-1228. doi: 10.3892/etm.2014.1900

Masuda, Y., Kadokura, T., Lshii, M., Takada, K., and Kitajima, J. (2015). Hinesol, a compound isolated from the essential oils of Atractylodes lancea rhizome, inhibits cell growth and induces apoptosis in human leukemia HL-60 cells. J. Nat. Med. 69, 332-339. doi: 10.1007/s11418-015-0897-5

Masuda, Y., Kawazoe, N., Nakajo, S., Yoshida, T., Kuroiwa, Y., and Nakaya, K. (1995). Bufalin induces apoptosis and infuences the expression of apoptosis-related genes in human leukemia cells. Leuk. Res. 19, 549-556. doi: 10.1016/0145-2126(95)00031-I

Nakao, Y., and Fusetani, N. (2007). Enzyme inhibitors from marine invertebrates. J. Nat. Prod. 70, 689-710. doi: 10.1021/np060600x

Peng, B., Xu, L., Cao, F., Wei, T., Yang, C., Uzan, G., et al. (2010). HSP90 inhibitor, celastrol, arrests human monocytic leukemia cell U937 at G0/G1 in thiol-containing agents reversible way. Mol. Cancer 9:79. doi: 10.1186/1476-4598-9-79

Peng, F., Wan, F., Xiong, L., Peng, C., Dai, M., and Chen, J. (2014). In vitro and in vivo antibacterial activity of Pogostone. Chin. Med. J. 127, 4001-4005. Available online at: http://124.205.33.103:81/ch/reader/create_pdf.aspx?file_ no $=20140494 \&$ year_id $=2014 \& q u a r t e r \_i d=23 \& f a l g=1$

Piotrowska, H., Kucinska, M., and Murias, M. (2012). Biological activity of piceatannol: leaving the shadow of resveratrol. Mutat. Res. 750, 60-82. doi: 10.1016/j.mrrev.2011.11.001

Qian, T., Cai, Z., Wong, R. N., Mak, N. K., and Jiang, Z. H. (2005). In vivo rat metabolism and pharmacokinetic studies of ginsenoside Rg3. J. Chromatogr. B Analyt. Technol. Biomed. Life Sci. 816, 223-232. doi: 10.1016/j.jchromb.2004.11.036

Qiang, S., and Li, M. (2017). Chamaejasmine induces apoptosis in HeLa cells through the PI3K/Akt signaling pathway. Anticancer Drugs. 28, 40-50. doi: 10.1097/CAD.0000000000000424

Qu, W., Wang, Y., Wu, Q., Liu, J., and Hao, D. (2015). Emodin inhibits HMGB1induced tumor angiogenesis in human osteosarcoma by regulating SIRT1. Int. J. Clin. Exp. Med. 8, 15054-15064. Available online at: http://europepmc.org/ abstract/MED/26628989

Rajendran, P., Li, F., Shanmugam, M. K., Kannaiyan, R., Goh, J. N., Wong, K. F., et al. (2012). Celastro suppresses growth and induces apoptosis of human hepatocellular carcinoma through the modulation of STAT3/JAK2 signaling cascade in vitro and in vivo. Cancer Prev. Res. (Phila). 5, 631-643. doi: 10.1158/1940-6207.CAPR-11-0420

Saha, A., Kuzuhara, T., Echigo, N., Fujii, A., Suganuma, M., and Fujiki, H. (2010). Apoptosis of human lung cancer cells by curcumin mediated through upregulation of "growth arrest and DNA damage inducible genes 45 and 153". Biol. Pharm. Bull. 33, 1291-1299. doi: 10.1248/bpb.33.1291

Schiborr, C., Eckert, G. P., Rimbach, G., and Frank, J. (2010). A validated method for the quantification of curcumin in plasma and brain tissue by fast narrowbore high-performance liquid chromatography with fluorescence detection. Anal. Bioanal. Chem. 397, 1917-1925. doi: 10.1007/s00216-010-3719-3

Sethi, G., Ahn, K. S., Pandey, M. K., and Aggarwal, B. B. (2007). Celastrol, a novel triterpene, potentiates TNF-induced apoptosis and suppresses invasion of tumor cells by inhibiting NF- $\mathrm{KB}$ regulated gene products and TAK1-mediated NF-KB activation. Blood 109, 2727-2735. doi: 10.1182/blood-2006-10-050807

Shan, X., Aziz, F., Tian, L. L., Wang, X. Q., Yan, Q., Liu, J. W. (2015). Ginsenoside Rg3-induced EGFR/MAPK pathway deactivation inhibits melanoma cell proliferation by decreasing FUT4/LeY expression. Int. J. Oncol. 46, 1667-1676. doi: $10.3892 /$ ijo.2015.2886

Sharma, P. S., Sharma, R., and Tyagi, R. (2008). Inhibitors of cyclindependent kinases: useful targets for cancer treatment. Curr. Cancer Drug Targets 8, 53-75. doi: $10.2174 / 156800908783497131$

Shen, Y. C., Chou, C. J., Chiou, W. F., and Chen, C. F. (2001). Anti-inflammatory effects of the partially purified extract of radix Stephaniae tetrandrae: comparative studies of its active principles tetrandrine and fangchinoline 
on human polymorphonuclear leukocyte functions. Mol. Pharmacol. 60, 1083-1090. Available online at: http://europepmc.org/abstract/MED/11641437

Shia, C. S., Hou, Y. C., Tsai, S. Y., Huieh, P. H., Leu, Y. L., and Chao, P. D. (2010). Differences in pharmacokinetics and ex vivo antioxidant activity following intravenous and oral administrations of emodin to rats. J. Pharm. Sci. 99, 2185-2195. doi: 10.1002/jps.21978

Shin, C. Y., Lee, W. J., Lee, E. B., Choi, E. Y., and Ko, K. H. (2002). Platycodin D and D3 increase airway mucin release in vivo and in vitro in rats and hamsters. Planta Med. 68, 221-225. doi: 10.1055/s-2002-23130

Siomboing, X., Gressier, B., Dine, T., Brunet, C., Luyckx, M., Cazin, M., et al. (2001). Investigation of the inhibitory effects of chelerythrine chloride on the translocation of the protein kinase C $\beta \mathrm{I}$, $\beta \mathrm{II}$, zeta in human neutrophils. Farmaco 56, 859-865. doi: 10.1016/S0014-827X(01)01165-X

Su, J. Y., Luo, X., Zhang, X. J., Deng, X. L., Su, Z. R., Zhou, L., et al. (2015). Immunosuppressive activity of pogostone on $\mathrm{T}$ cells: Blocking proliferation via $\mathrm{S}$ phase arrest. Int. Immunopharmacol. 26, 328-337. doi: 10.1016/j.intimp.2015.04.019

Sun, E., Xu, F., Qian, Q., Cui, L., Tan, X., and Jia, X. (2014). Ultra-performance liquid chromatography/quadrupole-time-of-flight mass spectrometry analysis of icariside II metabolites in rats. Nat. Prod. Res. 28, 1525-1529. doi: 10.1080/14786419.2014.921684

Sun, Z. J., Chen, G., Hu, X., Zhang, W., Liu, Y., Zhu, L. X., et al. (2010). Activation of PI3K/Akt/IKK- $\alpha / \mathrm{NF}-\kappa \mathrm{B}$ signaling pathway is required for the apoptosis evasion in human salivary adenoid cystic carcinoma: its inhibition by quercetin. Apoptosis 15, 850-863. doi: 10.1007/s10495-010-0497-5

Tan, P., Zhong, W., and Cai, W. (2000). Clinical study on treatment of 40 cases of malignant brain tumor by elemene emulsion injection. Zhongguo Zhong Xi Yi Jie He Za Zhi. 20, 645-648. Available online at: http://www.cnki.net/KCMS/ detail/detail.aspx?QueryID $=4 \&$ CurRec $=3 \&$ filename $=Z Z X J 200009002 \&$ dbname $=$ CJFD2000\&dbcode

Tao, L., Zhou, L., and Zheng, L. Y. (2006). Elemene displays anti-cancer ability on laryngeal cancer cells in vitro and in vivo. Cancer Chem. Pharmacol. 58, 24-34. doi: 10.1007/s00280-005-0137-x

Tao, L., Zhou, L., Zheng, L. Y., and Yao, M. (2005). Inhibition of eIF families expression and angiogenesis for human laryngeal carcinoma by elemene administration. Chin. J. Otorhinolaryngol. Head Neck Surg. 40, 840-845. Available online at: http://www.cnki.net/KCMS/detail/detail.aspx?QueryID= 0\&CurRec $=1 \&$ filename $=$ ZHEB200511009\&dbname $=$ CJFD2005\&dbcode

Teachey, D. T., Obzut, D. A., Cooperman, J., Fang, J., Carroll, M., Choi, J. K., et al. (2006). The mTOR inhibitor CCI-779 induces apoptosis and inhibits growth in preclinical models of primary adult human ALL. Blood. 107, 1149-1155. doi: 10.1182/blood-2005-05-1935

Tian, L., Shen, D., Li, X., Shan, X., Wang, X., Liu, J., et al. (2016). Ginsenoside Rg3 inhibits epithelial-mesenchymal transition (EMT) and invasion of lung cancer by down-regulating FUT4. Oncotarget 7, 1619-1632. doi: 10.18632/oncotarget.6451

Tokunaga, E., Oki, E., Egashira, A., Sadanaga, N., Morita, M., Kakeji, Y.,et al. (2008). Deregulation of the Akt pathway in human cancer. Curr. Cancer Drug Targets 8, 27-36. doi: 10.2174/156800908783497140

Tsuneki, H., Ma, E. L., Kobayashi, S., Sekizaki, N., Maekawa, k., Sasaoka, T., et al. (2005). Antiangiogenic activity of $\beta$-eudesmol in vitro and in vivo. Eur. J. Pharmacol. 512, 105-115. doi: 10.1016/j.jphar.2005.02.035

Usta, M., Wortelboer, H. M., Vervoort, J., Boersma, M. G., Rietjens, I. M., van Bladeren, P. J., et al. (2007). Human glutathione S- transferase-mediated glutathione conjugation of curcumin and efflux of these conjugates in Caco-2 cells. Chem. Res. Toxicol. 20, 1895-1902. doi: 10.1021/tx7002245

Vian, M. A., Tomao, V., Gallet, S., Coulomb, P. O., and Lacombe, J. M. (2005). Simple and rapid method for cis- and trans-resveratrol and piceid isomers determination in wine by high-performance liquid chromatography using Chromolith columns. J. Chromatogr. A. 1085, 224-229. doi: 10.1016/j.chroma.2005.05.083

Vrba, J., Dolezel, P., Vicar, J., Modrianský, M., and Ulrichová, J. (2008). Chelerythrine and dihydrochelerythrine induce G1 phase arrest and bimodal cell death in human leuke-mia HL-60 cells. Toxicol. In vitro 22, 1008-1017. doi: 10.1016/j.tiv.2008.02.007

Wagner, E. F., and Nebreda, A. R. (2009). Signal integration by JNK and p38 MAPK pathways in cancer development. Nat. Rev. Cancer 9, 537-549. doi: $10.1038 / \mathrm{nrc} 2694$
Wang, C., Zhang, Z., Wang, Y., and He, X. (2016). Cytotoxic constituents and mechanism from peganum hrmala. Chem. Biodiver. 13, 961-968. doi: $10.1002 / \mathrm{cbdv} .201500384$

Wang, D., Hu, J., Lv, L., Xia, X., Liu, J., and Li, X. (2013). Enhanced inhibitory effect of curcumin via reactive oxygen species generation in human nasopharyngeal carcinoma cells following purple-light irradiation. Oncol. Lett. 6, 81-85. doi: $10.3892 / 01.2013 .1341$

Wang, G., Li, X., Huang, F., Zhao, J., Ding, H., Cunningham, C., et al. (2005). Antitumor effect of beta-elemene in non-small-cell lung cancer cells is mediated via induction of cell cycle arrest and apoptotic cell death. Cell. Mol. Life Sci. 62, 881-893. doi: 10.1007/s00018-005-5017-3

Wang, J. N., Liu, J. W., and Yan, Q. (2008). Effect of Ginsenoside Rg3 on the Epidermal Growth Factor Receptor Signaling Pathways in Human Breast Cancer Cell Line MCF-7. Dalian: Dalian Medical University.

Wang, Y., Deng, L., Zhong, H., Jiang, X., and Chen, J. (2011a). Natural plant extract tubeimoside I promotes apoptosis-mediated cell death in cultured human hepatoma (HepG2) cells. Biol. Pharm. Bull. 34, 831-838. doi: $10.1248 / \mathrm{bpb} .34 .831$

Wang, Y. H., Qiu, C., Wang, D. W., Hu, Z. F., Yu, B. Y., and Zhu, D. N. (2011). Identification of multiple constituents in the traditional Chinese medicine formula Sheng-Mai San and rat plasma after oral administration by HPLC-DAD-MS/MS. J. Pharm. Biomed. Anal. 54, 1110-1127. doi: 10.1016/j.jpba.2010.11.034

Wang, Y., Xie, B. F., Zhu, X. F., Feng, G. K., Deng, R., Liu, J. N., et al. (2006). The mechanism for SYUNZ-4 inducing apoptosis of U937 cells. Chin. J. Hematol. 27, 762-765. Available online at: http://www.cnki.net/KCMS/detail/ detail.aspx?QueryID $=40 \&$ CurRec $=2 \&$ filename $=$ ZHXY200611011\&dbname $=$ CJFD2006\&dbcode

Wang, Y., Zhao, Y., Liu, Y., Tian, L., and Jin, D. (2011b). Chamaejasmine inactivates Akt to trigger apoptosis in human hep-2 larynx carcinoma cells. Molecules 16, 8152-8164. doi: 10.3390/molecules 16108152

Wenzel, E., and Somoza, V. (2005).Metabolism and bioavailability of transresveratrol. Mol. Nutr. Food Res. 49, 472-481. doi: 10.1002/mnfr.200500010

Wu, J. F., Guan, M., Wong, P. F., Yu, H., Dong, J. C., and Xu, J. H. (2012). Icariside II potentiates paclitaxel-induced apoptosis in human melanoma A375 cells by inhibiting TLR4 signaling pathway. Food Chem. Toxicol. 50, 3019-3024. doi: 10.1016/j.fct.2012.06.027

Wu, J., Wan, Z., Yi, J., Wu, Y., Peng, W., and Wu, J. (2013a). Investigation of the extracts from Bidens pilosa Linn. var. radiata Sch. Bip. for antioxidant activities and cytotoxicity against human tumor cells. J. Nat. Med. 67, 17-26. doi: 10.1007/s11418-012-0639-x

Wu, J., Zuo, F., Du, J., Wong, P. F., Qin, H., and Xu, J. (2013b). Icariside II induces apoptosis via inhibition of the EGFR pathways in A431 human epidermoid carcinoma cells. Mol. Med. Rep. 8, 597-602. doi: 10.3892/mmr. 2013.1557

Xie, B. F., Feng, G. K., Huang, H., Liu, Z. C., Wu, H. Q., Huang, Z. S., et al. (2006a). Cytotoxicity and apoptosis induction of new naphthoquinone-like derivative TEISHNZ on human nasopharyngeal cancer cell. Chin. Trad. Herbal Drugs 37, 234-238. Available online at: http://www.cnki.net/KCMS/detail/ detail.aspx?QueryID $=36 \&$ CurRec $=26 \&$ filename $=$ ZCYO200602028\&dbname $=$ CJFD2006\&dbcode

Xie, B. F., Feng, G. K., Huang, H., Zhu, X. F., Wang, Y., Deng, R., et al. (2007). Antitumor effect of alkannin derivative, SYUNZ-4. Chin. Pharm. J. 42, 1384-1388.

Xie, B. F., Feng, G. K., Huang, H., Zhu, X. F., Zhou, J. M., Wang, Y., et al. (2006b). Investigation of antitumor effect of natural radixarnebiae seu Lithospermi naphthoquinone compounds and its derivatives. Chin. Pharmacol. Bull. 22, 505-507. Available online at: http://www.cnki.net/KCMS/detail/detail.aspx? QueryID $=28 \&$ CurRec $=5 \&$ filename $=$ YAOL200604029\&dbname $=$ CJFD2006\& dbcode

Xie, C. Y., Yang, W., Li, M., Ying, J., Tao, S. J., Li, K., et al. (2009). Apoptosis induced by delta-elemene in colorectal adenocarcinoma cells via a mitochondrial-mediated pathway. Yakugaku Zasshi. 129, 1403-1413. doi: 10.1248/yakushi.129.1403

Xie, H. T., Wang, G. J., Sun, J. G., Tucker, I., Zhao, X. C., Xie, Y. Y., et al. (2005). High performance liquid chromategraphic-mass spectrometric determination of ginsenoside $\mathrm{Rg} 3$ and its metabolites in rat plasma using solid-phase 
extraction for pharmacokinetic studies. J. Chromatogr. B Analyt. Technol. Biomed. Life Sci. 818, 167-173. doi: 10.1016/j.jchromb.2004.12.028

Xie, M. J., Ma, Y. H., Miao, L., Wang, Y., Wang, H. Z., Xing, Y. Y., et al. (2014). Emodin-provoked oxidative stress induces apoptosis in human colon cancer HCT116 cells through a p53-mitochondrial apoptotic pathway. Asian Pac. J. Cancer Prev. 15, 5201-5205. doi: 10.7314/APJCP.2014.15.13.5201

Xu, D. G., Lv, W., Dai, C. Y., Zhu, F. F., Xu, G. H., Ma, Z. J., et al. (2015). 2-(Pro-1-ynyl)-5-(5,6-dihydrox-ypenta-1,3-diynyl) Thiophene induces apoptosis through reactive oxygen species-mediated JNK activation in human colon cancer SW620 cells. Anat ec (Hoboken). 298, 376-385. doi: 10.1002/ar.23045

Xu, Q. J., Hou, L. L., Hu, G. Q., and Xie, S. Q. (2013). Molecular mechanism of ophiopogonin B induced cellular autophagy of human cervical cancer HeLa cells. Yao Xue Xue Bao. 48, 855-859. doi: 10.16438/j.0513-4870.2013.06.004

Yan, C., Xin-Ming, Q., Li-Kun, G., Lin-Lin, L., Fang-Ping, C., Ying, X., et al. (2006). Tetrandrine-induced apoptosis in rat primary hepatocytes is initiated from mitochondria: caspases and endonuclease $\mathrm{G}$ (Endo G) pathway. Toxicology 218, 1-12. doi: 10.1016/j.tox.2005.08.024

Yang, C. W., Chang, C. L., Lee, H. C., Chi, C. W., Pan, J. P., and Yang, W. C. (2012). Curcumin induce the apoptosis of human monocytic leukemia THP-1 cells via the activation of JNK/ERK pathways. BMC Complement Altern. Med. 12:22. doi: 10.1186/1472-6882-12-22

Yang, D., Wang, P., and Ren, X. (2015). Apoptosis induced by chamaejasmine in human osteosarcoma cells through p53 pathway. Tumour Biol. 36, 5433-5439. doi: 10.1007/s13277-015-3209-5

Yang, F., Chen, Y., Duan, W., Zhang, C., Zhu, H., and Ding, J. (2006). SH-7, a new synthesized shikonin derivative, exerting its potent antitumor activities as a topoisomerase inhibitor. Int. J. Cancer 119, 1184-1193. doi: 10.1002/ijc.21943

Yang, H., Chen, D., Cui, Q. C., Yuan, X., and Dou, Q. P. (2006). Celastrol, a triterpene extracted from the Chinese "Thunder of God Vine," is a potent proteasome inhibitor and suppresses human prostate cancer growth in nude mice. Cancer Res. 66, 4758-4765. doi: 10.1158/0008-5472.CAN-05-4529

Yang, J. B., Khan, M., He, Y. Y., Yao, M., Li, Y. M., Gao, H. W., et al. (2016). Tubeimoside-1 induces oxidative stress-mediated apoptosis and G0/G1phase arrest in human prostate carcinoma cells in vitro. Acta Pharmacol. Sin. 37, 950-962. doi: 10.1038/aps.2016.34

Yang, Q. H., Yang,J., Liu, G. Z., Wang, L., and Zhu, T. C., Gao, H.L., et al. (2013). Study on in vitro anti-tumor activity of Bidens bipinnata L. extract. Afr. J. Tradit. Complement Altern. Med. 10, 543-549. doi: 10.4314/ajtcam.v10i3.24

Yang, R., Piperdi, S., and Gorlick, R. (2008). Activation of the RAF/mitogenactivated protein/extracellular signal-regulated kinase/extracellular signal- regulated kinase pathway mediates apoptosis induced by chelery- thrine in osteosarcoma. Clin. Cancer Res. 14, 6396-6404. doi: 10.1158/1078-0432.CCR-07-5113

Yang, S., Liu, Y., Yang, Q. F., Xiang, J. X., Tang, Y. L., and Xu, G. Z. (2011). The antitumor effect of Macleaya cordata and its molecular mechanism research of inducting human telomere DNA to form the Four-stranded G-quadruplex. Chin. Herbal Med. 42, 738-742. Available online at: http:// www.cnki.net/KCMS/detail/detail.aspx?QueryID=12\&CurRec=3\&filename $=$ ZCYO201104029\&dbname=CJFD2011\&dbcode

Yao, Y. Q., Ding, X., Jia, Y. C., Huang, C. X., Wang, Y. Z., and Xu, Y. H. (2008). Anti-tumor effect of beta-elemene in glioblastoma cells depends on p38 MAPK activation. Cancer Lett. 264, 127-134. doi: 10.1016/j.canlet.2008.01.049

Yaoxian, W., Hui, Y., Yunyan, Z., Yanqin, L., Xin, G., and Xiaoke, W. (2013). Emodin induces apoptosis of human cervical cancer HeLa cells via intrinsic mitochondrial and extrinsic death receptor pathway. Cancer Cell Int. 13:71. doi: 10.1186/1475-2867-13-71

Yin, Y., Chen, W., Tang, C., Ding, H., Jang, J., Weng, M., et al. (2011). NF-кB, JNK and 53 pathways are involved in tubeimoside-1-induced apoptosis in HepG2 cells with oxidative stress and G(2)/M cell cycle arrest. Food Chem. Toxicol. 49, 3046-3054. doi: 10.1016/j.fct.2011.10.001

Yu, C. H., Kan, S. F., Pu, H. F., Jea Chien, E., and Wang, P. S. (2010). Apoptotic signaling in bufalin- and cinobufagin-treated androgen-dependent and -independent human prostate cancer cells. Cancer Sci. 99, 2467-2476. doi: 10.1111/j.1349-7006.2008.00966.x

Yu, H., Zhang, T., Cai, L., Qu, Y., Hu, S., Dong, G., et al. (2011).Chamaejasmine induces apoptosis in human lung adenocarcinoma A549 cells through a ROS-mediated mitochondrial pathway. Molecules 16, 8165-8180. doi: 10.3390/molecules16108165

Yu, L., Wang, L. T., and Chen, S. W. (2012). Dual character of Toll-like receptor signaling: Pro-tumorigenic effects and anti-tumor functions. Biochim. Biophys. Acta. 1835, 144-154. doi: 10.1016/j.bbcan.2012.10.006

Yu, R., Mandlekar, S., Tan, T. H., and Kong, A. N. (2000). Activation of p38 and c-Jun N-terminal kinase pathways and induction of apoptosis by chelerythrine do not require inhibition of protein kinase C. J. Biol. Chem. 275, 9612-9619. doi: 10.1074/jbc.275.13.9612

Yu, T. X., Ma, R. D., and Yu, L. J. (2001). Structure-activity relationship of tubeimosides in anti-inflammatory, antitumor, and antitumor-promoting effects. Acta Pharmacol. Sin. 22, 463-468.

Zhang, C. Y., Yi, J. M., Yuan, H. L., Chen, W. D., and Lu, C. H. (2014). Progress in pharmacokinetics of curcumin and its dosage forms. Anhui Med. Pharm. J. 18:1. doi: 10.3969/j.issn.1009-6469.2014.01.001

Zhang, D. M., Liu, J. S., Deng, L. J., Chen, M. F., Yiu, A., Cao, H. H., et al. (2013). Arenobufagin, a natural bufadienolide from toad venom, induces apoptosis and autophagy in human hepatocellular carcinoma cells through inhibition of PI3K/Akt/mTOR pathway. Carcinogenesis 34, 1331-1342. doi: 10.1093/carcin/bgt060

Zhang, J., Li, C. Y., Xu, M. J., Wu, T., Chu, J. H., Liu, S. J., et al. (2012). Oral bioavailability and gender-related pharmacokinetics of celastrol following administration of pure celastrol and its related tablets in rats. J. Ethnopharmacol. 144, 195-120. doi: 10.1016/j.jep.2012.09.005

Zhang, L., Nakaya, K., Yoshida, T., and Kuroiwa, Y. (1992). Induction by bufalin of differentiation of human leukemia cells HL60, U937, and ML1 toward macrophage/monocyte-like cells and its potent synergistic effect on the differentiation of human leukemia cells in combination with other inducers. Cancer Res. 52, 4634-4641.

Zhang, P., Jin, W. R., Shi, Q., He, H., Ma, Z. J., and Qu, H. B. (2008). Two novel thiophenes from Echinops grijissi Hance. J. Asian Nat. Prod. Res. 10, 977-981. doi: 10.1080/10286020802240467

Zhang, T., Yu, H., Dong, G., Cai, L., and Bai, Y. (2013). Chamaejasmine arrests cell cycle, induces apoptosis and inhibits nuclear NF- $\beta$ translocation in the human breast cancer cell line MDA-MB-231. Molecules 18, 845-858. doi: 10.3390/molecules 18010845

Zhang, W., Zhang, Q., Jiang, Y., Li, F., and Xin, H. (2016). Effects of ophiopogonin $\mathrm{B}$ on the proliferation and apoptosis of SGC 7901 human gastric cancer cells. Mol. Med. Rep. 13, 4981-4986. doi: 10.3892/mmr.2016.5198

Zhang, Y., Xu, X., and He, P. (2011). Tubeimoside-1 inhibits proliferation and induces apoptosis by increasing the Bax to Bcl-2 ratio and decreasing COX-2 expression in lung cancer A549 cells. Mol. Med. Rep. 4, 25-29. doi: $10.3892 / \mathrm{mmr} .2010 .379$

Zhao, Q., Li, P., Jiang, J., and Hu, P. (2016). Pharmacokinetics of single ascending doses and multiple doses of 20(S)-Ginsenoside Rg3 in Chinese Healthy Volunteers. Eur. J. Drug Metab Pharmacokinet. 41, 845-853. doi: $10.1007 / \mathrm{s} 13318-015-0304-3$

Conflict of Interest Statement: The authors declare that the research was conducted in the absence of any commercial or financial relationships that could be construed as a potential conflict of interest.

Copyright (c) 2017 Liu, Zhao, Cao, Zhang, Li and Lin. This is an open-access article distributed under the terms of the Creative Commons Attribution License (CC BY). The use, distribution or reproduction in other forums is permitted, provided the original author(s) or licensor are credited and that the original publication in this journal is cited, in accordance with accepted academic practice. No use, distribution or reproduction is permitted which does not comply with these terms. 